\title{
Effect of different conditions of storage on seed viability and seedling growth of six European wild fruit woody plants
}

\author{
Mikołaj Krzysztof Wawrzyniak ${ }^{1}$ (D) Marcin Michalak ${ }^{1,2}$ (D) Paweł Chmielarz $^{1}$ (D)
}

Received: 6 September 2019 / Accepted: 15 May 2020 / Published online: 15 June 2020

(C) The Author(s) 2020

\begin{abstract}
- Key message Malus sylvestris (L.) Mill., Pyrus communis (L.), Sorbus aucuparia (L.), Prunus avium (L.), Prunus padus (L.), and Cornus sanguinea (L.) are related, co-occurring species producing orthodox seeds. However, we observed differences in their response to storage conditions, such as storage at different seed moisture contents $(5 \%, 8 \%$, and $11 \%)$ and/or temperatures $\left(-3^{\circ} \mathrm{C},-18^{\circ} \mathrm{C}\right.$, and $\left.-196^{\circ} \mathrm{C}\right)$. Severe desiccation to ca. $5 \%$ of MC negatively affected seeds of M. sylvestris. Seeds of $P$. avium were sensitive to storage in $\mathrm{LN}$ or at $-18^{\circ} \mathrm{C}$. S. aucuparia seeds are best stored at $-3^{\circ} \mathrm{C}$, whereas $C$. sanguinea seeds tolerate desiccation and storage in LN. In general, species with deeper physiological dormancy ( $S$. aucuparia, P. padus, and $C$. sanguinea) tended to be more tolerant to desiccation and low temperatures. For all species, storage conditions did not affect seedling growth.

- Context Wild fruit woody species face many threats such as genetic loss, population fragmentation, and alien species; thus, their genetic variability should be preserved.

- Aims To examine the effect of storage conditions on seed viability and the initial growth of seedlings of six European wild fruit species: Malus sylvestris (L.) Mill., Pyrus communis (L.), Sorbus aucuparia (L.), Prunus avium (L.), Prunus padus (L.), and Cornus sanguinea (L.).

- Methods Seeds were desiccated to three different levels of moisture content (ca. 5, 8, or 11\%) and stored at three different temperatures $\left(-3^{\circ},-18^{\circ}\right.$, or $-196^{\circ} \mathrm{C}$; liquid nitrogen, $\left.\mathrm{LN}\right)$ for up to 3 years. Germination and seedling emergence tests were performed as well as measurement of seedling growth.
\end{abstract}

\begin{tabular}{l}
\hline Handling Editor: Erwin Dreyer \\
\hline Contribution of the co-authors \\
PC and MM conceived and designed the experimental work and collected \\
material; PC, MM, and MW performed the experiments; MW collected \\
data and made a statistical analysis of the results; MW, MM, and PC \\
analyzed and interpreted data; MW drafted the article; PC and MM \\
reviewed and revised the paper. All authors have approved the final \\
article.
\end{tabular}

Mikołaj Krzysztof Wawrzyniak

mikwaw@man.poznan.pl

Marcin Michalak

m.michalak@uwm.edu.pl

Paweł Chmielarz

pach@man.poznan.pl

1 Institute of Dendrology Polish Academy of Sciences, Parkowa 5, 62-035 Kórnik, Poland

2 Department of Plant Physiology, Genetics and Biotechnology, University of Warmia and Mazury in Olsztyn, Oczapowskiego 1A/ 103, 10-719 Olsztyn, Poland 
- Results Desiccation of M. sylvestris seeds from 10.7 to $4.9 \%$ significantly lowered germination from 91 to $77 \%$ and seedling emergence from 88 to $74 \%$. In P. avium, LN storage significantly inhibited seedling emergence, both in the laboratory and the greenhouse, but did not affect total seed germination. In P. communis, P. padus, and C. sanguinea, neither germination nor seedling emergence was affected by seed storage conditions. There were small or no differences in stem height and root collar diameter in the first year of seedling growth of stored seeds.

- Conclusion Species with deeper physiological dormancy (S. aucuparia, P. padus, C. sanguinea) tended to be more tolerant of various storage conditions. Seeds of $P$. padus and $C$. sanguinea can be stored long term at $-18{ }^{\circ} \mathrm{C}$ or in $\mathrm{LN}$ at $5-8 \% \mathrm{MC}$ without losing viability. $M$. sylvestris and $P$. avium seeds are sensitive to desiccation below $6 \% \mathrm{MC}$ or low temperature of storage at -18 ${ }^{\circ} \mathrm{C}$ or $-196{ }^{\circ} \mathrm{C}$, respectively. We observed that storage conditions had significant influence on germination and seedling emergence but had no effect on seedling growth after the first growing season.

Keywords Seeds storage $\cdot$ Cryopreservation $\cdot$ Seeds traits $\cdot$ Conservation $\cdot$ Seed banking

\section{Introduction}

Biodiversity is the multiplicity of life, including variation among genes, species, and functional traits, in an ecosystem and has a profound effect on the functioning of ecosystems (Cardinale et al. 2012). The benefits of biodiversity in forest ecosystems have been well recognized in recent years, indicating resistance to natural disturbances (drought, severe winds, etc.), greater ecosystem productivity, and higher resilience (Liang et al. 2016; Jactel et al. 2017; Isbell et al. 2015). However, Europe's forest biodiversity remains under pressure due to land-use changes, invasive species, pollution, habitat, and climate changes (EEA 2016). This results in declining species richness in European forests as well as in global forests (Hooper et al. 2005; Schulze et al. 2014; Forest Europe, 2015).

Some of the species that make the greatest contributions to broad-leaved forest ecosystem function are fruit-bearing trees and shrubs. They provide multiple ecosystem services as a source of nutrition, pollination, genetic variation for breeding programs, and even of valuable income for people living around them (Powell et al. 2013). Wild fruit trees are considered less economically important than timber species and thus have often been neglected in conservation programs. Although wild fruit species are usually not considered endangered by European countries, their genetic diversity is threatened (Dirlewanger et al. 2002; Larsen et al. 2006; Wünsch and Hormaza 2007; Urrestarazu et al. 2016). Wild fruit trees are usually pioneer or intermediate species with weak competitive ability (Stephan et al. 2003; Russell 2003). Even considering their usually broad natural distribution in Europe due to their rare occurrence and scattered distribution pattern, populations are disappearing at an alarming rate (Coart et al. 2003). Their high light and soil demands, as well as slow growth, often result in low natural regeneration restricted to forest ecotones (Stephan et al. 2003; Russell 2003). A number of wild species often hybridize with cultivated species, leading to loss of their true wild form and genetic swamping (Fellenberg et al. 2000; Bleeker et al. 2007). The plantation-based model of fruit collection, as well as the lack of a uniform plan for preserving genetic resources in most of these species in the EU, leads to a further decrease in these populations (Wolf et al. 1999). Nevertheless, a number of wild fruit tree populations registered in the EUFGIS database for forest genetic resources are underrepresented and restricted to few countries in comparison with timber species. Therefore, more efforts to conserve the genetic resources of those species must be made.

One very efficient method for conserving the genetic resources of temperate forest trees is seed banks (FAO 2014). All wild fruit tree species from temperate and boreal regions produce orthodox seeds that can be stored for long periods of time at a low seed moisture content, below 5\%. Such desiccation tolerance allows the storage of seeds beyond average tree lifespan at a conventional temperature of $-20{ }^{\circ} \mathrm{C}$ (Pritchard et al. 2014) and later use in reintroduction programs. Although the total number of temperate tree species stored in seed banks is rather high, interspecies genetic diversity is generally not well conserved (FAO 2015). In addition to conventional methods, cryopreservation in liquid nitrogen ( $\mathrm{LN})$ is used as a secure backup for plant genetic resources. Cryopreservation is usually utilized for storing recalcitrant seeds, but due to its simple methodology, it is used for many orthodox seeds as well (Plitta et al. 2013). Effective seed cryopreservation has been proven for many temperate forest tree species, e.g., Alnus glutinosa L. (Chmielarz 2010), Corylus avellana L. (Michalak et al. 2013), Malus sieversii M.Roem. (Kushnarenko et al. 2010), Fraxinus excelsior L. (Chmielarz 2009a), Prunus armeniaca L. (Jaganathan et al. 2015), Populus nigra L. (Michalak et al. 2015a), and Prunus padus L. (Popova et al. 2016).

In our study, we examined seed storage and seedling growth in 6 wild fruit species: European crab apple (Malus sylvestris L.), European pear (Pyrus communis L.), mountainash (Sorbus aucuparia L.), wild cherry (Prunus avium L.), bird cherry (Prunus padus L.), and common dogwood (Cornus sanguinea L.). All described species suffer from fragmentation and disappearance of their natural habitats as 
mentioned earlier. In the case of the endangered European crab apple, the hybridization between this species and the domesticated apple could lead to the extinction of its wild populations (Reim et al. 2012). On the other hand, populations of bird cherry have to compete for habitats with highly invasive species such as black cherry ( $P$. serotina; Pairon et al. 2010). Nevertheless, apart from European crab apple and wild cherry, due to their usage in fruit production, information about seed storage behavior in the scientific literature is very limited and has not been properly examined. However, with the current climate and environmental changes, it is essential to assess the best possible storage conditions for effective conservation of these often-neglected species.

Seeds stored in gene banks must produce plants capable of reproduction in natural conditions, and high seedling quality is crucial for the initial success of any reforestation program (Grossnickle 2012). Often, seedling death is the result of environmental stress, animal grazing, disease, or insects. However, in many cases, survival can be significantly increased with good-quality planting stock (Campo et al. 2010). Seed storage conditions and practices have a strong influence on seed quality and therefore on seedlings. The effects of these practices on early seedling establishment need to be understood to produce high-quality seedlings that have a high probability of being "coupled" into forest ecosystems and reproducing (Grossnickle 2005). To our knowledge, studies examining seedling quality after storage are still rare. Recent publications assessing this subject confirm a possible effect on seedling quality both in annual plants (Marshall and Lewis 2004; Arguedas et al. 2018) and in woody species (Benamirouche et al. 2018).

The aim of this study was to examine the seed biology of 6 wild fruit tree species before and during storage under controlled conditions for 3 years. Our research questions were as follows: how do storage temperature and seed moisture content affect seed germination, both in controlled and field conditions? Do desiccation-tolerant seeds always tolerate storage at ultra-low temperatures $\left(-196^{\circ} \mathrm{C}\right)$ and does it affect subsequent seedling growth? What are the possibilities for ex situ conservation in nurseries, seed, and cryobanks of examined species?

\section{Material and methods}

\subsection{Plant material}

Mature seeds of the six tested species, European crab apple (Malus sylvestris L.), European pear (Pyrus communis L.), mountain-ash (Sorbus aucuparia L.), wild cherry (Prunus avium L.), bird cherry (P. padus L.), and common dogwood (Cornus sanguinea L.), were collected between May and September 2012 (Table 1) in natural stands in Poland (Wawrzyniak et al. 2020). Seed lots of each species were collected from individual trees (2-3), with the exception of European crab apple, where seeds from three adjacent individuals were mixed together. All experiments were conducted on whole seeds, with $P$. avium, $P$. padus, and $C$. sanguinea seeds consisting of endocarp. All tested species produce fleshy fruit; in order to obtain the seeds, collected fruits were pressed and seeds were extracted from the pulp, as described by Suszka et al. (1996). Then, seeds were air-dried in ambient conditions $\left(20^{\circ} \mathrm{C}\right)$ until they reached approximately $11 \%$ moisture content (control). Seeds were stored at $3{ }^{\circ} \mathrm{C}$ until the start of the experiment (1-2 months depending on species).

\subsection{The moisture content of the seeds}

Seed moisture content (MC) refers to the seed-containing embryo and seed coat. MC was calculated on a fresh weight basis (\%) using the formula:

$$
\mathrm{MC} 1=\frac{(\mathrm{FW} 1-\mathrm{DW}) 100}{\mathrm{FW} 1}
$$

where $\mathrm{MC}_{1}$ is the moisture content, $\mathrm{FW}_{1}$ is the initial fresh weight, and DW is the dry weight. The MC of the seeds was adjusted prior to seed storage with desiccation over activated silica gel to obtain two levels of MC: $5 \%$ and $8 \%$. The adjustment of the MC of seeds was based on the FW of the seeds, according to the formula:

$\mathrm{FW} 2=\frac{\mathrm{FW} 1\left(100-\mathrm{MC}_{1}\right)}{100-\mathrm{MC} 2}$

where $\mathrm{FW}_{2}$ is the desired weight and $\mathrm{MC}_{2}$ is the desired moisture content. The moisture content of the seeds was achieved specified by drying in the oven at $103 \pm 2{ }^{\circ} \mathrm{C}$ for $17 \mathrm{~h}(4$ replicates of 10 seeds). The exact seed MC levels achieved are shown in Table 2.

\subsection{Seed storage}

Seeds of each species were dry-stored at three levels of approximate $\mathrm{MC}(5,8$, and $11 \%$; Table 2), in plastic air-sealed bags at temperatures of $-3{ }^{\circ} \mathrm{C},-18^{\circ} \mathrm{C}$, or cryopreserved at $-196^{\circ} \mathrm{C}$ for 12,24 , and 36 months. As a control, we used nonstored seeds at approximately $11 \%$ MC. Cryopreserved seeds in sealed polypropylene bags were directly immersed in liquid nitrogen (LN). After storage, seeds were thawed in a water bath at $40{ }^{\circ} \mathrm{C}$ for $10 \mathrm{~min}$. Subsequently, seeds were placed in a stratification substrate and underwent stratification.

\subsection{Stratification and germination}

After each storage interval and prior germination and seedling emergence tests, seeds of all the examined species underwent 
Table 1 Location and date of the seeds from the six tested species

\begin{tabular}{|c|c|c|c|}
\hline Species & Seeds collection date & Place & Coordinates \\
\hline Malus sylvestris & 29 Sep 2012 & Kolumna & $\mathrm{N} 51^{\circ} 36^{\prime} 51.1 ; \mathrm{E} 19^{\circ} 11^{\prime} 41.6$ \\
\hline Pyrus communis & 7 Sep 2012 & Łopuchówko & $\mathrm{N} 52^{\circ} 35^{\prime} 31.6 ; \mathrm{E} 17^{\circ} 05^{\prime} 11.5$ \\
\hline Sorbus aucuparia & 6 Sep 2012 & Mosina & $\mathrm{N} 52^{\circ} 14^{\prime} 40.0 ; \mathrm{E} 16^{\circ} 51^{\prime} 00.0$ \\
\hline Prunus avium & 17 May 2012 & Śnieciska & $\mathrm{N} 52^{\circ} 11^{\prime} 41.0 ; \mathrm{E} 17^{\circ} 10^{\prime} 53.0$ \\
\hline Prunus padus & 26 Jun 2012 & Koniko & $\mathrm{N} 52^{\circ} 18^{\prime} 38.0 ; \mathrm{E} 17^{\circ} 00^{\prime} 54.0$ \\
\hline Cornus sanguinea & 29 Aug 2012 & Błażejewko & $\mathrm{N} 52^{\circ} 12^{\prime} 51.0 ; \mathrm{E} 17^{\circ} 06^{\prime} 07.0$ \\
\hline
\end{tabular}

a species-specific stratification process, as presented in Table 3. The stratification substrate was composed of a moist mixture (v/v, 1:1) of quartz sand (fraction $>1 \mathrm{~mm}$ ) with sieved peat of $\mathrm{pH} 3.5-4.5$. Seeds were mixed with the substrate at a ratio of 1:3 and placed in loosely sealed plastic containers. The condition of the seeds and the substrate was checked every 2 weeks. Stratification continued until the appearance of the first germinating seeds $(\leq 5 \%)$.

Directly after stratification, germination and seedling emergence tests were conducted in a laboratory under controlled conditions. Tests were performed in a growth chamber at cyclically alternating temperatures of $3 \% / 20^{\circ} \mathrm{C}$ with an interval of $16 / 8 \mathrm{~h}$. Seeds with a radicle of $\geq 3 \mathrm{~mm}$ were counted as germinated. Germinated seeds were examined weekly, counted, and eliminated until the last seed germinated. After the test, non-germinated seeds were cut and evaluated as healthy and dormant or decayed. During the germination test, the total germination percentage (GP), as well as the mean germination time (MGT or $\bar{T}$ ), was calculated according to the formula given by Ranal and Santana (2006) based on Labouriau (1983). Germination time was given in weeks and counted from the beginning of cold stratification.

$\bar{T}=\frac{\sum_{i=1}^{k} N_{i} T_{i}}{\sum_{i=1}^{k} N_{i}}$

where $T_{i}$ is the time from the start of the experiment to the $i$ th observation and $N_{i}$ is the number of seeds germinated in the $i$ th time (the number of germinated seeds corresponding to the $i$ th

Table 2 Moisture content of each tested species

\begin{tabular}{llll}
\hline Species & \multicolumn{2}{l}{ Moisture content $(\%)$} \\
\cline { 2 - 4 } Malus sylvestris & 4.9 & 8.5 & 10.7 \\
\hline Pyrus communis & 5.3 & 7.1 & 11.9 \\
Sorbus aucuparia & 5.5 & 8.4 & 11.1 \\
Prunus avium & 5.5 & 8.0 & 11.2 \\
Prunus padus & 5.9 & 8.3 & 11.4 \\
Cornus sanguinea & 5.5 & 8.0 & 11.0 \\
\hline
\end{tabular}

observation); $k$ is the last observation.

Seedling emergence (SE) tests were conducted in a similar way using a mixture of sand and peat. Stratified seeds were sown in plastic boxes and covered with a $1 \mathrm{~cm}$ substrate layer. Seedling emergence tests were conducted at the same temperatures as germination tests. The seed was regarded as emerged when cotyledons and epicotyl were observed above ground. After seedlings reached $2-3 \mathrm{~cm}$ in height, boxes were moved into the chamber with light and a temperature of $20{ }^{\circ} \mathrm{C}$. A sprouting index (SI) was calculated using the same formula as for calculating MGT, counted from the end of stratification. For germination and seedling emergence tests, 3 replicates of 30 seeds or 4 replicates of 50 seeds (in the case of mountainash and common dogwood) were used. For each test, separate seed samples were used.

\subsection{Seedling emergence and further seedling growth in a greenhouse}

In addition to the laboratory tests, a field emergence test was conducted. Stratified seeds were sown into plastic containers (FlexiFrame, BCC Sweden), with each seed in a separate cell, and placed in random blocks in the greenhouse. Seeds were placed into a mixture of peat, perlite (v/v, 2:1), and longlasting mineral fertilizer (Osmocote Extract 5-6 M 15-912 + $2 \mathrm{MgO}+\mathrm{TE}, 2-4.5 \mathrm{~mm})$. The test was performed on 3 replicates of 30 seeds or 4 replicates of 50 seeds (in the case of mountain-ash and common dogwood). One month after

Table 3 Stratification method used to induce germination in the six species

\begin{tabular}{lll}
\hline Species & \multicolumn{2}{l}{ Stratification } \\
\cline { 2 - 3 } & Temperature $\left({ }^{\circ} \mathrm{C}\right)$ & Time (weeks) \\
\hline Malus sylvestris & 3 & 11 \\
Pyrus communis & 3 & 15 \\
Sorbus aucuparia & $25 / 3$ & $2 / 20$ \\
Prunus avium & $20 / 3 / 20 / 3$ & $2 / 2 / 2 / 13$ \\
Prunus padus & $25 / 3 / 25 / 3$ & $2 / 2 / 2 / 22$ \\
Cornus sanguinea & $15 \sim 20 / 3$ & Daily change 6/24 \\
\hline
\end{tabular}


sowing, seedlings were counted. In autumn, after the vegetation period, all 1-year-old seedlings were measured for their height $(\mathrm{H})$ and root collar diameter (RCD). These tests were repeated each year during the 3 -year seed storage period. The temperature of the air and ground in the greenhouse was recorded during the experiment (Table 7).

\subsection{Statistical analysis}

The fixed effects of storage conditions on germination and seedling emergence were evaluated separately using a generalized linear model (GZLM) with a binomial distribution with loglink function (Ranal and Santana 2006). For the germination rate and sprouting index comparison, a linear regression model was used. Germination means used in statistical analyses were counted from 3 to 4 replicates (for each 30-50 seeds), each obtained from separate germination tests. A three-way analysis of variance (ANOVA) with interaction between main effects (storage time, moisture content, and storage temperature) was used in the linear regression model (Table 9). For GZLM, special analysis was based on deviance (Carvalho et al. 2018). For multiple comparisons between treatments, we adjusted $p$ values using Bonferroni-Holm method. For the linear regression models, we tested normality and equal variance assumptions of residuals by examining the plots of residuals. For growth analysis (height and root collar diameter measurements), a nonparametric KruskalWallis test was performed ( $p<0.05$; from agricolae package). For all statistical analyses of the data, $\mathrm{R}$ statistical software $(\mathrm{R}$ Core Team 2020) was used.

\section{Results}

\subsection{Effects of storage conditions on seed germination}

After the third year of storage, seeds' average germination capacity of all species was above $80 \%$, regardless of the storage conditions used. The main effects (storage time, seed MC, and storage temperature) had visible impact on seed germination and seedling emergence process. The interaction effects on germination were recorded between storage time and seed MC in bird cherry and between storage time and temperature in common pear as well as wild cherry (Table 8). The MC of stored seeds mainly affected germination of crab apple and mountain-ash. Different storage temperatures had major effect on wild cherry seedling emergence. Although common dogwood seeds germinated and emerged at high percentage regardless of the storage conditions used, nonstored seeds germinated significantly better than stored seeds. The mean time to germinate and seedling emergence index in most cases were alike. The seedling emergence tests were more sensitive on influence of storage conditions and therefore better indicate seed quality after the storage in comparison with germination test.

\subsubsection{European crab apple}

The best results were for European crab apple seeds stored at $18{ }^{\circ} \mathrm{C}$ at $8.5 \%$ seed MC, where germination and seedling emergence both in the laboratory and in the greenhouse were high, at approximately $93 \%, 89 \%$, and $83 \%$ and similar for each tested year of storage, respectively (Fig. 2). Germination after storage at $-3{ }^{\circ} \mathrm{C}$ showed a slight but significant decrease. The germination percentage was significantly lower after 1 and 3 years of storage than that of nonstored and seeds that were stored for 2 years (Table 4). The mean germination time was the highest after 3 years of storage: 12.2 weeks after the start of stratification. Seedling emergence both in the laboratory and in the greenhouse significantly decreased in each tested year. The nonstored seed emergence was $90.7 \%$ in the laboratory and $91.5 \%$ in the greenhouse, in comparison with $76 \%$ and $78 \%$ emerged after the third year of storage, respectively. The mean time of seedling emergence varied after each year of storage, with the lowest after the first year (2.1 weeks) and the highest after the second year ( 2.6 weeks) of seed storage. The temperature used for storage did not alter the germination percentage, which was between 85 and $88 \%$ (Table 5). Seed desiccation to $4.9 \%$ significantly lowered germination, from $92 \%$ in the control to $77 \%$ (Table 6). However, the mean germination time was a week faster (11.4 weeks) in strongly desiccated seeds than in the control (12.3 weeks). A similar effect was recorded for seedling emergence, which was significantly lower in seeds desiccated to $4.9 \%$ both in the laboratory and in the greenhouse. Desiccated seeds of European crab apple (5.5\%) had a significant decrease in seedling emergence after storage at each tested temperature. Seedling emergence of $M$. sylvestris seeds stored at $-196{ }^{\circ} \mathrm{C}$ decreased after the first year of storage, regardless of seed MC.

\subsubsection{European pear}

In general, nonstored seeds of European pear (P. communis) germinated at a slightly but significantly higher percentage (99\%) than stored seeds (96-97\%; Table 4). After the first year of storage of seeds desiccated to $7.1 \% \mathrm{MC}$ and stored at $-196{ }^{\circ} \mathrm{C}$, we recorded some decrease in all values of the conducted tests, but after the third year of storage, seeds maintained their germination ability at the same level as the control seeds (Fig. 3). The mean germination time was 16 weeks after the start of desiccation in each tested year. Seedling emergence was the highest in the nonstored control and after the third year of storage (95-97\%). However, the mean time of seedling emergence differed significantly: after 1 year of storage, seedlings emerged almost 1 week faster ( 1.3 weeks) than after the other tested storage times (approximately 2 weeks). Seedling emergence in the greenhouse was significantly higher after the third year of storage (93\%) than for nonstored seeds (83\%). Seedling emergence after exposure in seeds 
Table 4 Mean germination percentage (GP), mean germination time (MGT), and seedling emergence (SE) in laboratory and greenhouse, and sprouting index (SI) for 6 tested species after 3 years of storage. Statistical tests were run for each species separately

\begin{tabular}{|c|c|c|c|c|c|c|c|c|c|c|}
\hline \multirow[t]{2}{*}{ Species } & \multirow[t]{2}{*}{ Index } & \multicolumn{9}{|c|}{ Storage time, years } \\
\hline & & Nonstored & 1 & 2 & 3 & & Nonstored & 1 & 2 & 3 \\
\hline \multirow[t]{3}{*}{$\begin{array}{l}\text { Malus } \\
\quad \text { sylvestris }\end{array}$} & $\mathrm{GP}, \%$ & $\begin{array}{r}90.7 \pm \\
1.34 \mathrm{a}\end{array}$ & $\begin{array}{l}85.8 \pm \\
2.21 \mathrm{~b}\end{array}$ & $\begin{array}{r}90.4 \pm \\
1.48 \mathrm{a}\end{array}$ & $\begin{array}{r}80.0 \pm \\
1.89 \mathrm{c}\end{array}$ & $\begin{array}{l}\text { SE in laboratory, } \\
\%\end{array}$ & $90.7 \pm 1.3 \mathrm{a}$ & $\begin{array}{r}81.2 \pm \\
1.65 b\end{array}$ & $\begin{array}{r}82.5 \pm \\
2.7 \mathrm{~b}\end{array}$ & $\begin{array}{r}76.3 \pm \\
2.09 \mathrm{c}\end{array}$ \\
\hline & \multirow[t]{2}{*}{$\begin{array}{l}\text { MGT, } \\
\text { weeks }\end{array}$} & \multirow[t]{2}{*}{-} & \multirow[t]{2}{*}{$\begin{array}{r}12.0 \pm \\
0.08 \mathrm{a}\end{array}$} & \multirow[t]{2}{*}{$\begin{array}{r}12.0 \pm \\
0.09 \mathrm{a}\end{array}$} & \multirow[t]{2}{*}{$12.2 \pm 0.1 b$} & SI, weeks & $2.4 \pm 0.08 b$ & $2.1 \pm 0.03 \mathrm{a}$ & $\begin{array}{l}2.6 \pm \\
0.03 \mathrm{c}\end{array}$ & $2.4 \pm 0.03 b$ \\
\hline & & & & & & $\begin{array}{l}\mathrm{SE} \text { in } \\
\quad \text { greenhouse, } \%\end{array}$ & $\begin{array}{l}91.5 \pm \\
0.82 \mathrm{a}\end{array}$ & $83.6 \pm 1.9 \mathrm{~b}$ & $\begin{array}{r}77.9 \pm \\
1.8 \mathrm{c}\end{array}$ & $\begin{array}{r}78.8 \pm \\
1.41 \mathrm{c}\end{array}$ \\
\hline \multirow[t]{3}{*}{$\begin{array}{l}\text { Pyrus } \\
\quad \text { communis }\end{array}$} & GP, $\%$ & $\begin{array}{l}98.9 \pm \\
0.31 \mathrm{a}\end{array}$ & $96 \pm 1.32 \mathrm{a}$ & $\begin{array}{r}96.3 \pm \\
0.8 \mathrm{a}\end{array}$ & $\begin{array}{l}97.7 \pm \\
0.66 \mathrm{a}\end{array}$ & $\begin{array}{l}\text { SE in laboratory, } \\
\%\end{array}$ & $96.7 \pm 0.5 \mathrm{a}$ & $\begin{array}{l}91.9 \pm \\
2.06 \mathrm{a}\end{array}$ & $\begin{array}{l}92.2 \pm \\
1.27 \mathrm{a}\end{array}$ & $\begin{array}{l}94.8 \pm \\
1.01 \mathrm{a}\end{array}$ \\
\hline & \multirow[t]{2}{*}{$\begin{array}{l}\text { MGT, } \\
\text { weeks }\end{array}$} & \multirow[t]{2}{*}{-} & \multirow[t]{2}{*}{$\begin{array}{c}16.0 \pm \\
0.01 \mathrm{a}\end{array}$} & \multirow[t]{2}{*}{$\begin{array}{c}16.0 \pm \\
0.01 \mathrm{a}\end{array}$} & \multirow[t]{2}{*}{$\begin{array}{l}16.1 \pm \\
0.02 b\end{array}$} & SI, weeks & $2.1 \pm 0.02 \mathrm{c}$ & $1.3 \pm 0.02 \mathrm{a}$ & $\begin{array}{l}2.0 \pm \\
0.05 \mathrm{~b}\end{array}$ & $2.3 \pm 0.03 \mathrm{~d}$ \\
\hline & & & & & & $\begin{array}{l}\mathrm{SE} \text { in } \\
\quad \text { greenhouse, } \%\end{array}$ & $\begin{array}{l}83.3 \pm \\
1.98 \mathrm{~b}\end{array}$ & $\begin{array}{l}84.6 \pm \\
2.84 \mathrm{ab}\end{array}$ & $\begin{array}{l}91.9 \pm \\
1.07 \mathrm{a}\end{array}$ & $\begin{array}{l}92.8 \pm \\
1.73 \mathrm{a}\end{array}$ \\
\hline \multirow[t]{3}{*}{$\begin{array}{l}\text { Sorbus } \\
\qquad \text { aucuparia }\end{array}$} & GP, $\%$ & $\begin{array}{r}84.7 \pm \\
0.81 \mathrm{a}\end{array}$ & $\begin{array}{r}72.3 \pm \\
1.38 \mathrm{c}\end{array}$ & $\begin{array}{r}75.1 \pm \\
1.2 \mathrm{c}\end{array}$ & $\begin{array}{c}79.5 \pm \\
0.94 \mathrm{~b}\end{array}$ & $\begin{array}{l}\text { SE in laboratory, } \\
\%\end{array}$ & $\begin{array}{c}77.0 \pm \\
1.23 \mathrm{a}\end{array}$ & $\begin{array}{l}68.1 \pm \\
1.23 b\end{array}$ & $\begin{array}{l}67.5 \pm \\
1.17 b\end{array}$ & $\begin{array}{c}67.7 \pm \\
1.38 b\end{array}$ \\
\hline & \multirow[t]{2}{*}{$\begin{array}{l}\text { MGT, } \\
\text { weeks }\end{array}$} & \multirow[t]{2}{*}{-} & \multirow[t]{2}{*}{$\begin{array}{r}20.5 \pm \\
0.03 b\end{array}$} & \multirow[t]{2}{*}{$\begin{array}{r}20.3 \pm \\
0.04 \mathrm{a}\end{array}$} & \multirow[t]{2}{*}{$\begin{array}{l}20.4 \pm \\
\quad 0.04 \mathrm{ab}\end{array}$} & SI, weeks & $1.7 \pm 0.03 \mathrm{~b}$ & $1.9 \pm 0.02 \mathrm{c}$ & $\begin{array}{l}1.9 \pm \\
0.03 \mathrm{c}\end{array}$ & $1.6 \pm 0.02 \mathrm{a}$ \\
\hline & & & & & & $\begin{array}{l}\text { SE in } \\
\quad \text { greenhouse, } \%\end{array}$ & $\begin{array}{c}85.5 \pm \\
1.11 \mathrm{a}\end{array}$ & $73.3 \pm 1.9 b$ & $\begin{array}{l}65.5 \pm \\
1.57 \mathrm{c}\end{array}$ & $\begin{array}{c}85.9 \pm \\
1.16 \mathrm{a}\end{array}$ \\
\hline \multirow[t]{3}{*}{ Prunus avium } & $\mathrm{GP}, \%$ & $\begin{array}{l}87.0 \pm \\
1.00 \mathrm{~b}\end{array}$ & $\begin{array}{r}90.0 \pm \\
1.63 \mathrm{a}\end{array}$ & $\begin{array}{r}86.0 \pm \\
1.3 \mathrm{~b}\end{array}$ & $\begin{array}{l}89.9 \pm \\
1.77 \mathrm{a}\end{array}$ & $\begin{array}{l}\text { SE in laboratory, } \\
\%\end{array}$ & $\begin{array}{r}89.3 \pm \\
1.14 \mathrm{a}\end{array}$ & $\begin{array}{r}75.8 \pm \\
3.16 \mathrm{c}\end{array}$ & $\begin{array}{r}73.7 \pm \\
3.38 \mathrm{c}\end{array}$ & $\begin{array}{l}81.2 \pm \\
3.03 \mathrm{~b}\end{array}$ \\
\hline & \multirow[t]{2}{*}{$\begin{array}{l}\text { MGT, } \\
\text { weeks }\end{array}$} & \multirow[t]{2}{*}{-} & \multirow[t]{2}{*}{$\begin{array}{l}15.8 \pm \\
0.12 b\end{array}$} & \multirow[t]{2}{*}{$\begin{array}{c}15.9 \pm \\
0.13 b\end{array}$} & \multirow[t]{2}{*}{$15.6 \pm 0.1 \mathrm{a}$} & SI, weeks & $2.7 \pm 0.02 \mathrm{a}$ & $4.0 \pm 0.04 b$ & $\begin{array}{l}4.0 \pm \\
0.05 b\end{array}$ & $4.3 \pm 0.05 c$ \\
\hline & & & & & & $\begin{array}{l}\mathrm{SE} \text { in } \\
\quad \text { greenhouse, } \%\end{array}$ & $\begin{array}{l}85.9 \pm \\
1.15 \mathrm{~b}\end{array}$ & $\begin{array}{l}77.2 \pm \\
3.32 \mathrm{c}\end{array}$ & $\begin{array}{l}78.6 \pm \\
2.8 \mathrm{bc}\end{array}$ & $\begin{array}{r}88.8 \pm \\
1.94 \mathrm{a}\end{array}$ \\
\hline \multirow[t]{3}{*}{ Prunus padus } & GP, $\%$ & $\begin{array}{r}89.3 \pm \\
0.86\end{array}$ & $\begin{array}{r}88.3 \pm \\
1.35\end{array}$ & $\begin{array}{r}89.6 \pm \\
1.27\end{array}$ & $90.9 \pm 1.33$ & $\begin{array}{l}\text { SE in laboratory, } \\
\%\end{array}$ & $\begin{array}{r}83.7 \pm \\
1.09 \mathrm{a}\end{array}$ & $\begin{array}{l}68.8 \pm \\
2.59 \mathrm{~b}\end{array}$ & $\begin{array}{l}79.9 \pm \\
1.64 \mathrm{a}\end{array}$ & $\begin{array}{c}79.6 \pm \\
1.25 \mathrm{a}\end{array}$ \\
\hline & \multirow[t]{2}{*}{$\begin{array}{l}\text { MGT, } \\
\text { weeks }\end{array}$} & \multirow[t]{2}{*}{$\begin{array}{l}24.1 \pm \\
0.06 \mathrm{a}\end{array}$} & \multirow[t]{2}{*}{$\begin{array}{l}24.6 \pm \\
0.07 \mathrm{~b}\end{array}$} & \multirow[t]{2}{*}{$\begin{array}{l}23.9 \pm \\
0.05 \mathrm{a}\end{array}$} & \multirow[t]{2}{*}{$\begin{array}{l}24.7 \pm \\
0.06 \mathrm{~b}\end{array}$} & SI, weeks & $2.7 \pm 0.04 \mathrm{~b}$ & $2.7 \pm 0.04 \mathrm{~b}$ & $\begin{array}{l}2.4 \pm \\
0.04 \mathrm{a}\end{array}$ & $2.8 \pm 0.02 \mathrm{~b}$ \\
\hline & & & & & & $\begin{array}{l}\mathrm{SE} \text { in } \\
\quad \text { greenhouse, \% }\end{array}$ & $\begin{array}{l}86.3 \pm \\
2.06 \mathrm{ab}\end{array}$ & $\begin{array}{c}89.8 \pm \\
1.07 \mathrm{a}\end{array}$ & $84 \pm 1.45 b$ & $\begin{array}{l}88.8 \pm \\
1.26 \mathrm{ab}\end{array}$ \\
\hline \multirow[t]{3}{*}{$\begin{array}{l}\text { Cornus } \\
\quad \text { sanguinea }\end{array}$} & GP, $\%$ & $\begin{array}{c}96.8 \pm \\
0.56 \mathrm{a}\end{array}$ & $\begin{array}{c}93.6 \pm \\
0.73 b\end{array}$ & $\begin{array}{r}92.7 \pm \\
0.7 \mathrm{~b}\end{array}$ & $\begin{array}{l}92.7 \pm \\
0.87 \mathrm{~b}\end{array}$ & $\begin{array}{l}\text { SE in laboratory, } \\
\%\end{array}$ & $\begin{array}{c}97.3 \pm \\
0.52 \mathrm{a}\end{array}$ & $\begin{array}{l}91.7 \pm \\
0.87 \mathrm{~b}\end{array}$ & $\begin{array}{l}87.2 \pm \\
0.92 \mathrm{~d}\end{array}$ & $\begin{array}{c}90.1 \pm \\
0.78 \mathrm{c}\end{array}$ \\
\hline & $\begin{array}{l}\text { MGT, } \\
\text { weeks }\end{array}$ & $\begin{array}{c}27.0 \pm \\
0.06 \mathrm{~b}\end{array}$ & $\begin{array}{r}26.4 \pm \\
0.06 \mathrm{a}\end{array}$ & $\begin{array}{c}27.2 \pm \\
0.06 \mathrm{~b}\end{array}$ & $\begin{array}{c}27.6 \pm \\
0.05 \mathrm{c}\end{array}$ & SI, weeks & $5.4 \pm 0.02 \mathrm{~d}$ & $4.6 \pm 0.03 b$ & $\begin{array}{l}4.4 \pm \\
0.03 a\end{array}$ & $5.3 \pm 0.03 \mathrm{c}$ \\
\hline & & & & & & $\begin{array}{l}\mathrm{SE} \text { in } \\
\quad \text { greenhouse, \% }\end{array}$ & $\begin{array}{l}65.2 \pm \\
1.69 \mathrm{ab}\end{array}$ & $\begin{array}{l}64.7 \pm \\
1.56 \mathrm{ab}\end{array}$ & $\begin{array}{c}61.3 \pm \\
1.32 \mathrm{~b}\end{array}$ & $\begin{array}{c}66.7 \pm \\
1.19 \mathrm{a}\end{array}$ \\
\hline
\end{tabular}

Index means in the same row marked with the same letter are not significantly different at $p<0.05$. Means without letter marks are not significantly different at $p>0.05$

stored in LN was significantly lower (90\%) than the emergence for seeds stored at $-18(97 \%)$ and $-3{ }^{\circ} \mathrm{C}(96 \%$; Table 5). Seedling emergence in the greenhouse was $83 \%$ after storage in LN, $92 \%$ after storage at $-18{ }^{\circ} \mathrm{C}$, and $90 \%$ after storage at $-3{ }^{\circ} \mathrm{C}$. Seed moisture content had little or no effect on seed germination and emergence (Table 6). The highest germination percentage $(99 \%)$ was recorded at $7.1 \%$ MC. Seedling emergence in the laboratory was significantly lower for seeds desiccated to $5.3 \%(91 \%)$ than for those in the control treatment (95\%). There were no significant differences between seedling emergence percentages in the greenhouse; at all tested MC levels, the percentage was $87-89 \%$. Seeds of
P. communis desiccated to ca. 5\% were more vulnerable to storage at $-196{ }^{\circ} \mathrm{C}$. Higher MC during storage in LN resulted in better germination percentage and seedling emergence in greenhouse.

\subsubsection{Mountain-ash}

The seeds of mountain-ash ( $S$. aucuparia) had significantly lower germination and seedling emergence in the laboratory after storage in all tested conditions in comparison with nonstored seeds. The germination percentage after the first and second year was $10 \%$ lower than in the control seeds 
Table 5 Mean germination percentage (GP), mean germination time (MGT), and seedling emergence (SE) in laboratory and greenhouse, and sprouting index (SI) for 6 tested species at different storage temperatures. Statistical tests were run for each species separately

\begin{tabular}{|c|c|c|c|c|c|c|c|c|}
\hline \multirow[t]{2}{*}{ Species } & \multirow[t]{2}{*}{ Index } & \multicolumn{7}{|c|}{ Storage temperature, ${ }^{\circ} \mathrm{C}$} \\
\hline & & -3 & -18 & -196 & & -3 & -18 & -196 \\
\hline \multirow[t]{3}{*}{ Malus sylvestris } & $\mathrm{GP}, \%$ & $85.3 \pm 1.92$ & $88.2 \pm 1.51$ & $86.7 \pm 1.56$ & SE in laboratory, $\%$ & $83.2 \pm 1.57 \mathrm{a}$ & $84.5 \pm 1.72 \mathrm{a}$ & $80.3 \pm 2.36 \mathrm{a}$ \\
\hline & MGT, weeks & $12.0 \pm 0.1$ & $12.0 \pm 0.1$ & $12.1 \pm 0.09$ & SI, weeks & $2.4 \pm 0.05 b$ & $2.3 \pm 0.05 \mathrm{a}$ & $2.4 \pm 0.05 \mathrm{ab}$ \\
\hline & & & & & $\mathrm{SE}$ in greenhouse, $\%$ & $83.5 \pm 1.41$ & $84.4 \pm 1.54$ & $80.8 \pm 1.85$ \\
\hline \multirow[t]{3}{*}{ Pyrus communis } & $\mathrm{GP}, \%$ & $97.8 \pm 0.55 \mathrm{a}$ & $98.1 \pm 0.57 \mathrm{a}$ & $95.8 \pm 1.01 \mathrm{a}$ & SE in laboratory, $\%$ & $95.5 \pm 0.81 \mathrm{a}$ & $96.6 \pm 0.52 \mathrm{a}$ & $89.6 \pm 1.61 b$ \\
\hline & MGT, weeks & $16.0 \pm 0.02 \mathrm{a}$ & $16.0 \pm 0.02 \mathrm{a}$ & $16.1 \pm 0.02 b$ & SI, weeks & $2.0 \pm 0.07 \mathrm{a}$ & $1.9 \pm 0.07 \mathrm{a}$ & $1.9 \pm 0.07 \mathrm{a}$ \\
\hline & & & & & $\mathrm{SE}$ in greenhouse, $\%$ & $89.5 \pm 1.43 \mathrm{ab}$ & $91.7 \pm 1.4 \mathrm{a}$ & $83.2 \pm 2.32 b$ \\
\hline \multirow[t]{3}{*}{ Sorbus aucuparia } & GP, $\%$ & $80.1 \pm 0.99 \mathrm{a}$ & $76.7 \pm 1.15 b$ & $77 \pm 1.29 b$ & SE in laboratory, $\%$ & $72.2 \pm 1.18 \mathrm{a}$ & $68.8 \pm 1.1 \mathrm{~b}$ & $69.2 \pm 1.34 \mathrm{ab}$ \\
\hline & MGT, weeks & $20.4 \pm 0.04$ & $20.4 \pm 0.04$ & $20.4 \pm 0.03$ & SI, weeks & $1.8 \pm 0.03$ & $1.7 \pm 0.03$ & $1.8 \pm 0.03$ \\
\hline & & & & & $\mathrm{SE}$ in greenhouse, $\%$ & $79.5 \pm 1.55$ & $77.5 \pm 1.82$ & $75.6 \pm 1.92$ \\
\hline \multirow[t]{3}{*}{ Prunus avium } & $\mathrm{GP}, \%$ & $92.0 \pm 0.94 \mathrm{a}$ & $90.6 \pm 0.93 \mathrm{a}$ & $82.1 \pm 1.25 b$ & SE in laboratory, $\%$ & $89.2 \pm 1.11 \mathrm{a}$ & $85.4 \pm 1.26 b$ & $65.5 \pm 2.96 \mathrm{c}$ \\
\hline & MGT, weeks & $15.4 \pm 0.03 a$ & $15.4 \pm 0.04 \mathrm{a}$ & $16.6 \pm 0.09 b$ & SI, weeks & $3.6 \pm 0.1 \mathrm{a}$ & $3.7 \pm 0.1 \mathrm{a}$ & $3.9 \pm 0.12 b$ \\
\hline & & & & & $\mathrm{SE}$ in greenhouse, $\%$ & $90.4 \pm 1.16 \mathrm{a}$ & $87.5 \pm 1.03 b$ & $70 \pm 2.46 c$ \\
\hline \multirow[t]{3}{*}{ Prunus padus } & $\mathrm{GP}, \%$ & $88.9 \pm 1.03$ & $90.9 \pm 0.95$ & $88.7 \pm 1.15$ & SE in laboratory, $\%$ & $77.8 \pm 1.74$ & $78.2 \pm 2.2$ & $78.0 \pm 1.24$ \\
\hline & MGT, weeks & $24.4 \pm 0.08$ & $24.3 \pm 0.08$ & $24.3 \pm 0.07$ & SI, weeks & $2.7 \pm 0.04$ & $2.7 \pm 0.04$ & $2.7 \pm 0.04$ \\
\hline & & & & & $\mathrm{SE}$ in greenhouse, $\%$ & $86.8 \pm 1.27$ & $87.3 \pm 1.42$ & $87.5 \pm 1.36$ \\
\hline \multirow[t]{3}{*}{ Cornus sanguinea } & GP, $\%$ & $93.5 \pm 0.71$ & $94.6 \pm 0.62$ & $93.8 \pm 0.68$ & SE in laboratory, $\%$ & $92.3 \pm 0.73$ & $91.7 \pm 0.87$ & $90.8 \pm 0.97$ \\
\hline & MGT, weeks & $27.1 \pm 0.07$ & $27.1 \pm 0.08$ & $27 \pm 0.09$ & SI, weeks & $4.9 \pm 0.07$ & $4.9 \pm 0.07$ & $4.9 \pm 0.08$ \\
\hline & & & & & $\mathrm{SE}$ in greenhouse, $\%$ & $63.3 \pm 1.2$ & $64.3 \pm 1.44$ & $65.8 \pm 1.17$ \\
\hline
\end{tabular}

Index means in the same row marked with the same letter are not significantly different at $p<0.05$. Means without letter marks are not significantly different at $p>0.05$

(85\%; Table 4). The mean germination time was the lowest after the second year of storage (20.3 weeks). Seedling emergence in the laboratory also significantly decreased after storage. Seedling emergence in a greenhouse was significantly lower after the first and second years of storage. The highest germination percentage was recorded in seeds stored at $-3{ }^{\circ} \mathrm{C}$ $(80 \%)$ in comparison with $77 \%$ at both lower temperatures (Table 5). Similar results were recorded for seedling emergence in the laboratory, where emergence after storage at $3{ }^{\circ} \mathrm{C}$ was the highest $(72 \%)$. The temperature had no effect on either the mean germination time ( 20 weeks) or the sprouting index (1.8 weeks). Desiccated seeds of mountain-ash $(5.5 \%$ MC) had a significantly higher germination percentage and seedling emergence in the greenhouse compared with the control (11.1\% MC; Table 6). Seedling emergence in the laboratory was recorded at $67 \%$ for the control and $74 \%$ for desiccated seeds. In seeds of mountain-ash, all tested temperatures and MCs after the third year of storage resulted in high viability of seeds in comparison with the nonstored control. Only desiccated seeds ( 8.4 and 5.5\% MC) stored in LN had a significantly lower germination percentage after the third year. The most consistent results were recorded after 3 years of storage for seeds with $8.4 \% \mathrm{MC}$ at $-3{ }^{\circ} \mathrm{C}$ (Fig. 4).

\subsubsection{Wild cherry}

After 3 years of storage of wild cherry seeds, its germination rate remained high $(89 \%)$ at temperatures of $-18{ }^{\circ} \mathrm{C}$ and -3 ${ }^{\circ} \mathrm{C}$. Storage in LN significantly decreased seedling emergence both in the laboratory and in the greenhouse; however, germination after storage in $\mathrm{LN}$ remained high. We obtained the best results at a storing temperature of $-18{ }^{\circ} \mathrm{C}$ in seeds with $11.2 \% \mathrm{MC}$ (Fig. 5). The seeds germinated at a similar level in the control and after all tested storage years (Table 4). Seedling emergence in the laboratory in all the tested conditions was significantly lower after storage (73-81\%) than in the control (89\%). The mean time of seedling emergence was 1 week faster in fresh nonstored seeds, 2.7 weeks in comparison with 4.3 weeks after the third year of storage. After the third year of storage, seedling emergence in the greenhouse was $89 \%$ in comparison with the control result, $86 \%$ of germinated seeds. The storage temperature significantly affected the percentage and the rate of germination and seedling emergence. After storage in $\mathrm{LN}$, the germination percentage decreased from $92 \%$ at $-3{ }^{\circ} \mathrm{C}$ and $91 \%$ at $-18{ }^{\circ} \mathrm{C}$ to $82 \%$, and the mean germination time was significantly longer, increasing from 15.4 to 16.6 weeks (Table 5). Seedling 
Table 6 Mean germination percentage (GP), mean germination time (MGT), and seedling emergence (SE) in laboratory and greenhouse, and sprouting index (SI) for 6 tested species at different seed moisture contents. Statistical tests were run for each species separately

\begin{tabular}{|c|c|c|c|c|c|c|c|c|}
\hline \multirow[t]{2}{*}{ Species } & \multirow[t]{2}{*}{ Index } & \multicolumn{7}{|c|}{ Moisture content, $\%$} \\
\hline & & 11 & 8 & 5 & & 11 & 8 & 5 \\
\hline \multirow[t]{3}{*}{ Malus sylvestris } & GP, $\%$ & $92.0 \pm 1.1 \mathrm{a}$ & $91.1 \pm 0.84 \mathrm{a}$ & $77.0 \pm 1.61 \mathrm{~b}$ & SE in laboratory, $\%$ & $85.2 \pm 1.11 b$ & $88.6 \pm 1.08 \mathrm{a}$ & $74.3 \pm 2.38 \mathrm{c}$ \\
\hline & MGT, weeks & $12.3 \pm 0.03 b$ & $12.4 \pm 0.04 b$ & $11.4 \pm 0.04 \mathrm{a}$ & SI, weeks & $2.3 \pm 0.04 \mathrm{~b}$ & $2.5 \pm 0.05 \mathrm{c}$ & $2.2 \pm 0.05 \mathrm{a}$ \\
\hline & & & & & $\mathrm{SE}$ in greenhouse, $\%$ & $86.5 \pm 1.39 \mathrm{a}$ & $84.9 \pm 1.51 \mathrm{a}$ & $77.4 \pm 1.56 \mathrm{~b}$ \\
\hline \multirow[t]{3}{*}{ Pyrus communis } & GP, $\%$ & $97.4 \pm 0.48 \mathrm{a}$ & $98.5 \pm 0.57 \mathrm{a}$ & $95.7 \pm 1.03 \mathrm{a}$ & SE in laboratory, $\%$ & $95.3 \pm 0.71 \mathrm{a}$ & $95.0 \pm 0.77 \mathrm{a}$ & $91.4 \pm 1.72 \mathrm{a}$ \\
\hline & MGT, weeks & $16.0 \pm 0.02$ & $16.1 \pm 0.03$ & $16.0 \pm 0.02$ & SI, weeks & $1.95 \pm 0.06 b$ & $1.9 \pm 0.07 \mathrm{ab}$ & $1.9 \pm 0.07 \mathrm{a}$ \\
\hline & & & & & $\mathrm{SE}$ in greenhouse, $\%$ & $88.5 \pm 2$ & $88.7 \pm 1.41$ & $87.2 \pm 2.12$ \\
\hline \multirow[t]{3}{*}{ Sorbus aucuparia } & GP, $\%$ & $76.5 \pm 1.07 \mathrm{~b}$ & $77.1 \pm 1.3 b$ & $80 \pm 1.06 \mathrm{a}$ & SE in laboratory, $\%$ & $66.8 \pm 0.97 \mathrm{c}$ & $70.0 \pm 1.05 b$ & $73.5 \pm 1.42 \mathrm{a}$ \\
\hline & MGT, weeks & $20.4 \pm 0.03 b$ & $20.5 \pm 0.04 b$ & $20.3 \pm 0.03 a$ & SI, weeks & $1.8 \pm 0.02 \mathrm{~b}$ & $1.7 \pm 0.03 \mathrm{a}$ & $1.7 \pm 0.03 \mathrm{a}$ \\
\hline & & & & & $\mathrm{SE}$ in greenhouse, $\%$ & $78.1 \pm 1.38$ & $77.1 \pm 1.71$ & $77.4 \pm 2.18$ \\
\hline \multirow[t]{3}{*}{ Prunus avium } & GP, $\%$ & $90.2 \pm 0.94 a$ & $88.6 \pm 1.33 \mathrm{a}$ & $85.9 \pm 1.43 \mathrm{a}$ & SE in laboratory, $\%$ & $82.0 \pm 2.2 \mathrm{a}$ & $81.3 \pm 2.58 \mathrm{a}$ & $76.7 \pm 2.98 \mathrm{~b}$ \\
\hline & MGT, weeks & $15.7 \pm 0.1 \mathrm{a}$ & $15.8 \pm 0.14 \mathrm{ab}$ & $15.9 \pm 0.12 b$ & SI, weeks & $3.7 \pm 0.11 \mathrm{a}$ & $3.7 \pm 0.1 \mathrm{a}$ & $3.8 \pm 0.11 \mathrm{a}$ \\
\hline & & & & & $\mathrm{SE}$ in greenhouse, $\%$ & $82.6 \pm 2.26$ & $82.9 \pm 2.18$ & $82.4 \pm 2.34$ \\
\hline \multirow[t]{3}{*}{ Prunus padus } & $\mathrm{GP}, \%$ & $89.0 \pm 0.91$ & $89.8 \pm 1.02$ & $89.7 \pm 1.23$ & SE in laboratory, $\%$ & $78.5 \pm 1.42$ & $79.9 \pm 1.57$ & $75.6 \pm 2.15$ \\
\hline & MGT, weeks & $24.4 \pm 0.08$ & $24.2 \pm 0.08$ & $24.4 \pm 0.07$ & SI, weeks & $2.6 \pm 0.04 \mathrm{a}$ & $2.7 \pm 0.04 b$ & $2.6 \pm 0.05 \mathrm{ab}$ \\
\hline & & & & & $\mathrm{SE}$ in greenhouse, $\%$ & $86.8 \pm 1.34$ & $88.1 \pm 1.46$ & $86.8 \pm 1.23$ \\
\hline \multirow[t]{3}{*}{ Cornus sanguinea } & GP, $\%$ & $93.7 \pm 0.67$ & $93.4 \pm 0.74$ & $94.8 \pm 0.57$ & SE in laboratory, $\%$ & $92 \pm 0.91$ & $91.6 \pm 0.93$ & $91.1 \pm 0.75$ \\
\hline & MGT, weeks & $27.0 \pm 0.07 \mathrm{a}$ & $27.1 \pm 0.09 b$ & $27.1 \pm 0.08 \mathrm{ab}$ & SI, weeks & $4.9 \pm 0.07 \mathrm{ab}$ & $5.0 \pm 0.07 \mathrm{~b}$ & $4.9 \pm 0.08 \mathrm{a}$ \\
\hline & & & & & SE in greenhouse, $\%$ & $63.9 \pm 1.28$ & $64.9 \pm 1.31$ & $64.7 \pm 1.26$ \\
\hline
\end{tabular}

Index means in the same row marked with the same letter are not significantly different at $p<0.05$. Means without letter marks are not significantly different at $p>0.05$

emergence in the laboratory after storage at traditional temperatures was $89 \%$ at $-3{ }^{\circ} \mathrm{C}$ and $85 \%$ at $-18{ }^{\circ} \mathrm{C}$, while seedling emergence for seeds stored in LN was $66 \%$. Seedling emergence in the greenhouse after LN storage was almost $20 \%$ lower than that of seeds stored at the other tested temperatures. The mean seedling emergence time was higher after LN storage. Desiccation of $P$. avium seeds to $5.5 \%$ slightly decreased germination from $90 \%$ at $11.2 \% \mathrm{MC}$ to $86 \%$ (Table 6). Seeds stored at higher MC levels germinated faster, from 15.9 weeks at $5.5 \% \mathrm{MC}$ to 15.7 weeks at $11.1 \%$ MC. Seedling emergence in the laboratory was the lowest for desiccated seeds, at $77 \%$. In the greenhouse, seedlings emerged at $82 \%$ for all tested MC levels.

\subsubsection{Bird cherry}

Storage conditions had little or no effect on bird cherry (P. padus) seed germination and seedling emergence (Fig. $6)$. Germination was similar among nonstored seeds and all storage times, varying from 88 to $91 \%$ (Table 4). The mean germination time varied at each year from 23.9 weeks after 2 years of storage to 24.7 weeks after the third year. Seedling emergence in the greenhouse showed no significant differences among all storage years except for the second year, where it was slightly lower $(84 \%)$ in comparison with the first and third years of storage (89-88\%). Seeds germinated in all the tested temperatures with a mean germination time of approximately 24 weeks after the start of the cold stratification phase. Desiccation of seeds did not result in changes in the germination percentage (89-90\%; Table 6) or the mean germination time ( 24 weeks).

\subsubsection{Common dogwood}

Seeds of common dogwood (C. sanguinea) were characterized by similar durability, in which the only factor that slightly affected germination and seedling emergence was storage time. Nonstored seeds of common dogwood germinated at 97\% in comparison with $93-94 \%$ for stored seeds (Table 4). The mean germination time varied from 26.4 weeks after the first year of storage to 27.6 weeks after the third year. Seedling emergence in the laboratory was significantly higher in nonstored seeds $(97 \%)$ and decreased in storage seeds (87$92 \%$ ). Additionally, the mean time of emergence varied each year, resulting in the fastest, 4.4 weeks in the seeds stored for 2 years, to the slowest, 5.4 weeks in nonstored seeds. The results of seedling emergence in the greenhouse were much lower than those in the laboratory, resulting in emergence between 
61 and $67 \%$. The temperature of storage had no effect on germination percentage or seedling emergence both in the laboratory and in the greenhouse (Table 5). Seeds germinated at a high level, 94-95\%, at all the tested temperatures, and the mean germination time was 27 weeks from the beginning of stratification. Seedling emergence in the laboratory was between 91 and $92 \%$, much higher than in the greenhouse, where it was $63-66 \%$ (Fig. 7). Similar results were obtained for different seed MC levels. At all MC levels, between 94 and $95 \%$ of seeds germinated with a mean time of 27 weeks (Table 6).

\subsection{Height and root collar diameter of seedlings}

The height of 1-year-old seedlings from seeds stored in controlled conditions was comparable in all tested conditions. All tested species' seedling height and diameter were the lowest in nonstored seeds and the highest after the third year of storage (Fig. 1a, d). In the case of seedlings of European crab apple, seeds stored at controlled temperatures did not differ among the tested temperatures, and seedling height varied from 34 to $36 \mathrm{~cm}$ (Fig. 1b, e). The root collar diameter in seedlings from seeds stored at $-3{ }^{\circ} \mathrm{C}$ was $3.92 \mathrm{~mm}$ and was significantly lower than that from seeds stored at other storage temperatures. The shortest seedlings $(33 \mathrm{~cm})$ were obtained from seeds stored at $8.5 \% \mathrm{MC}$, while seedlings grown from seeds with 5 and $10.7 \% \mathrm{MC}$ were statistically significantly taller (Fig. 1c, f). A similar result was obtained for European pear, in which the shortest seedlings grew from seeds stored at 7.1\% $\mathrm{MC}(34 \mathrm{~cm})$ in comparison with 35 and $36 \mathrm{~cm}$ for the heights of seedlings grown from seeds stored at 5.3 and $11.9 \% \mathrm{MC}$, respectively (Fig. 1c). The thickest root collar diameter was $4.28 \mathrm{~mm}$ in seedlings grown from seeds at $7.1 \% \mathrm{MC}$. The tallest seedlings were obtained from mountain-ash seeds stored at $-3{ }^{\circ} \mathrm{C}$, at $53 \mathrm{~cm}$, and they were $2 \mathrm{~cm}$ higher than seedlings grown from seeds stored at lower temperatures (Fig. 1b). The root collar diameter in mountain-ash was similar at all the tested temperatures and varied from 5.29 to $5.34 \mathrm{~mm}$. Seedlings grown from desiccated seeds $(5.5 \%)$ were $53 \mathrm{~cm}$ in height in comparison with 51 and $52 \mathrm{~cm}$ heights of seedlings grown from 8.4 and $11.1 \%$ of MC, respectively. Seedlings of wild cherry grown from cryostored seeds grew $2 \mathrm{~cm}$ less (34 $\mathrm{cm}$ ) than seedlings stored at higher temperatures (Fig. 1b). The thickest root collar diameter was obtained in seedlings from seeds stored at $-18{ }^{\circ} \mathrm{C}$. The height and root collar diameter were similar for all tested MC levels. The moisture content of the stored bird cherry seeds had no effect on the height of seedlings, which was $29 \mathrm{~cm}$ for all tested MC levels of seeds. The root collar diameter $(4.36 \mathrm{~mm})$ was slightly larger in seedlings grown from seeds with $8.3 \% \mathrm{MC}$. In common dogwood, seedlings grown from cryostored seeds had the smallest root collar diameter of $3.56 \mathrm{~mm}$, in comparison with 3.66 and $3.64 \mathrm{~mm}$ in seedlings from seeds stored at -3 or
$-18{ }^{\circ} \mathrm{C}$ (Fig. 1e). The shortest seedling, at $49 \mathrm{~cm}$, was grown from seeds stored at $11 \% \mathrm{MC}, 4 \mathrm{~cm}$ shorter than seedlings grown from seeds with greater MC. The root collar diameter for seedlings grown from seeds stored at $8 \% \mathrm{MC}$ was 3.51 $\mathrm{mm}$, in comparison with 3.7 and $3.65 \mathrm{~mm}$ for seedlings grown from seeds stored at $5.5 \%$ and $11 \%$ MCs, respectively.

\section{Discussion}

Seeds of the investigated species responded variously to storage conditions. Although they belong to the same storage behavior category (orthodox or uncertain in case of C. sanguinea according to the SID database) and originate from the same ecological niche, their MC and temperature during storage had different effects on germination and seedling emergence. Probert et al. (2009) showed that seed longevity is affected primarily by the environment and endosperm presence. Non-endospermic seeds from dry, hot environments tend to have a longer life span in storage. Oil content and seed mass, according to those authors, have no effect on seed longevity. However, the oligo-/disaccharide ratio in seeds plays an important role in seed longevity (Lin and Huang 1994). In our research, seeds were rather small, with 1000-seed weight of 7-32 g in Malus sylvestris, Pyrus communis, and Sorbus aucuparia, 52-84 g in Cornus sanguinea and Prunus padus, and $184 \mathrm{~g}$ in P. avium. The large size of $P$. avium seeds could have a negative effect during its freezing in LN. Also differences in seed coat thickness can influence seed longevity, as seeds with less permeable seed coats deteriorate slower (Debeaujon et al. 2000). Besides, Nguyen et al. (2012) show that dormancy in Arabidopsis mutants is negatively correlated with seed longevity. In our study, we observed that species with more complex dormancy (C. sanguinea, P. padus, and S. aucuparia; Table 6) tended to be more tolerant to both desiccation and storage temperature.

Storage of Malus sylvestris seeds at 5.5\% of MC in our experiments resulted in a decrease in all performed seed viability tests. Storage of seeds below 5\% of MC was considered to increase seed longevity by other authors (Perez-Garcia et al. 2009; Ellis 1995; Ellis et al. 1996). However, an experiment by Hong et al. (2005) shows that ultra-dry storage can be beneficial in ambient conditions but not always at subzero temperatures. This was also confirmed by experiments of Haiying et al. (2002) on tomato seeds (Solanum lycopersicum) stored at 2.3\% of MC for 13 years at $20^{\circ} \mathrm{C}$ and of Ellis et al. (1986), in which seed desiccation of Sesamum indicum from 5 to $2 \%$ of MC increased storage time 40-fold. Walters (2007) indicated that, below a critical moisture content, longevity does not increase with further drying. A similar conclusion was reported by Michalak et al. (2015b), as storage of European crab apple desiccated to $4 \%$ of MC also resulted in decreased germination and 


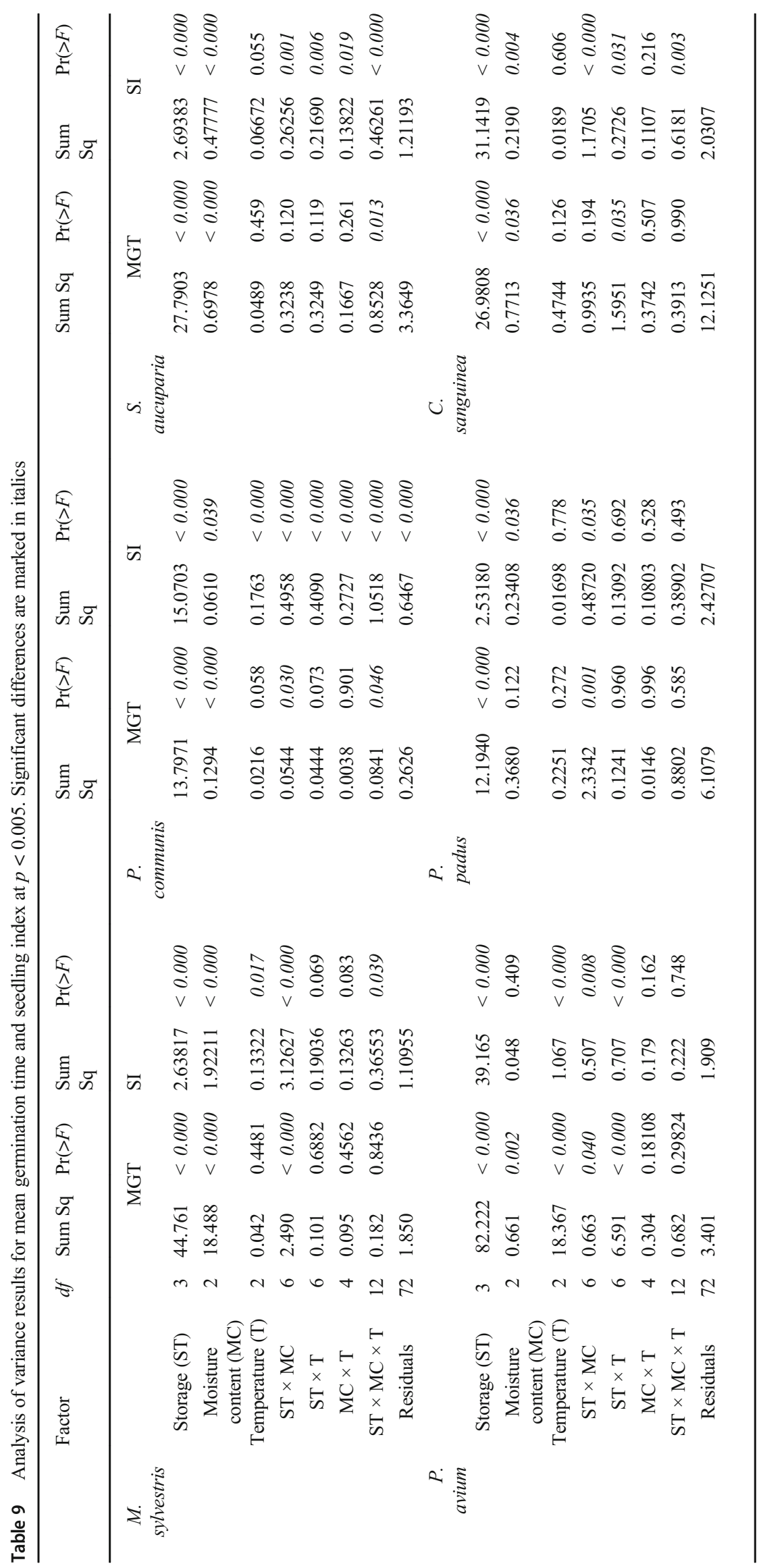



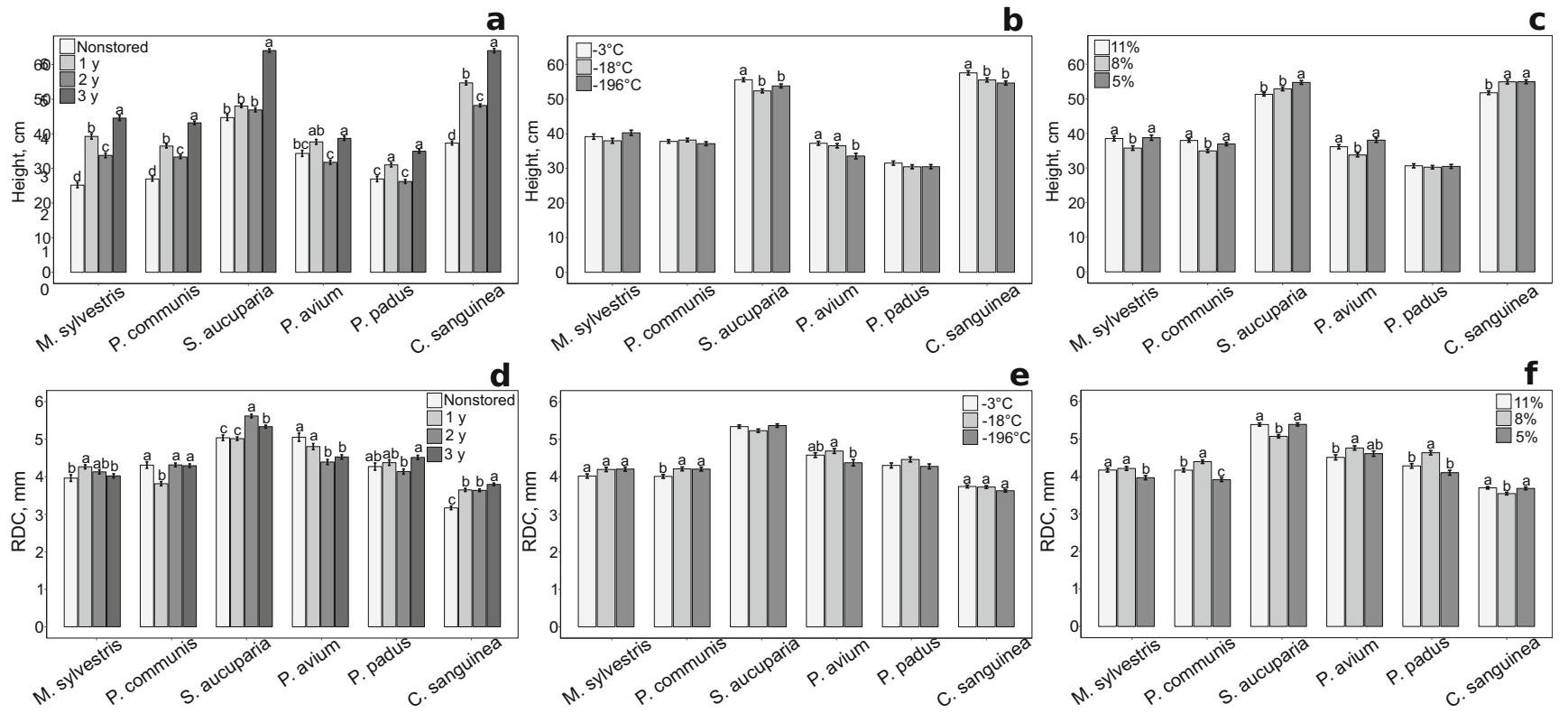

Fig. 1 Mean height $(\mathrm{H})$ and root collar diameter (RCD) for seedlings grown from seeds stored in controlled conditions. a, d Storage time. b, e Temperature. c, f Moisture content. Statistical tests were run for each

species separately. Means in the same row marked with the same letter are not significantly different at $p<0.05$, by Kruskal-Wallis test. Means without letter marks are not significantly different at $p>0.05$

seedling emergence. We noted that seed storage of M. sylvestris at MC 5.5\% in LN resulted in a significant decrease in seedling emergence. Despite the decline in seedling emergence, desiccated seeds of European crab apple tend to release dormancy a week earlier than the control. In general, desiccation plays a crucial role in the after-ripening process, which prepares seeds to germinate. As noted by Angelovici et al. (2010), gene expression and metabolic processes during seed desiccation strongly resemble those observed during germination. This suggests that one of the functions of the desiccation process is preparation for germination. Seed storage conditions of Pyrus communis affected neither germination nor seedling emergence. However, despite being desiccation-tolerant (to $\mathrm{MC}$ 5.3\%), seeds stored at low $\mathrm{MC}$ in $\mathrm{LN}$ germinated at a lower rate. There is little information about storing Sorbus aucuparia seeds in the literature. Gordon et al. (1992) recommend storage of Sorbus spp. at 6-8\% of MC, at 1$4{ }^{\circ} \mathrm{C}$ for up to 8 years. As reported by Granstrom (1987), mountain-ash seeds survive and remain viable for up to 5 years in the soil bank. In our experiment, nonstored seeds germinated faster and better than seeds stored for 1-2 years. This might be due to the delay in seed sowing caused by a lack of space in the growth chambers, as the proportion of decayed seeds after
Fig. 2 Germination and seedling emergence in laboratory and greenhouse of seeds of Malus sylvestris after 1, 2, and 3 years of storage in controlled conditions. One-way ANOVA; columns marked with the same letter are not significantly different at $p<$ 0.05 , by Tukey's test. Means without letter marks are not significantly different at $p<0.05$. Means \pm SE

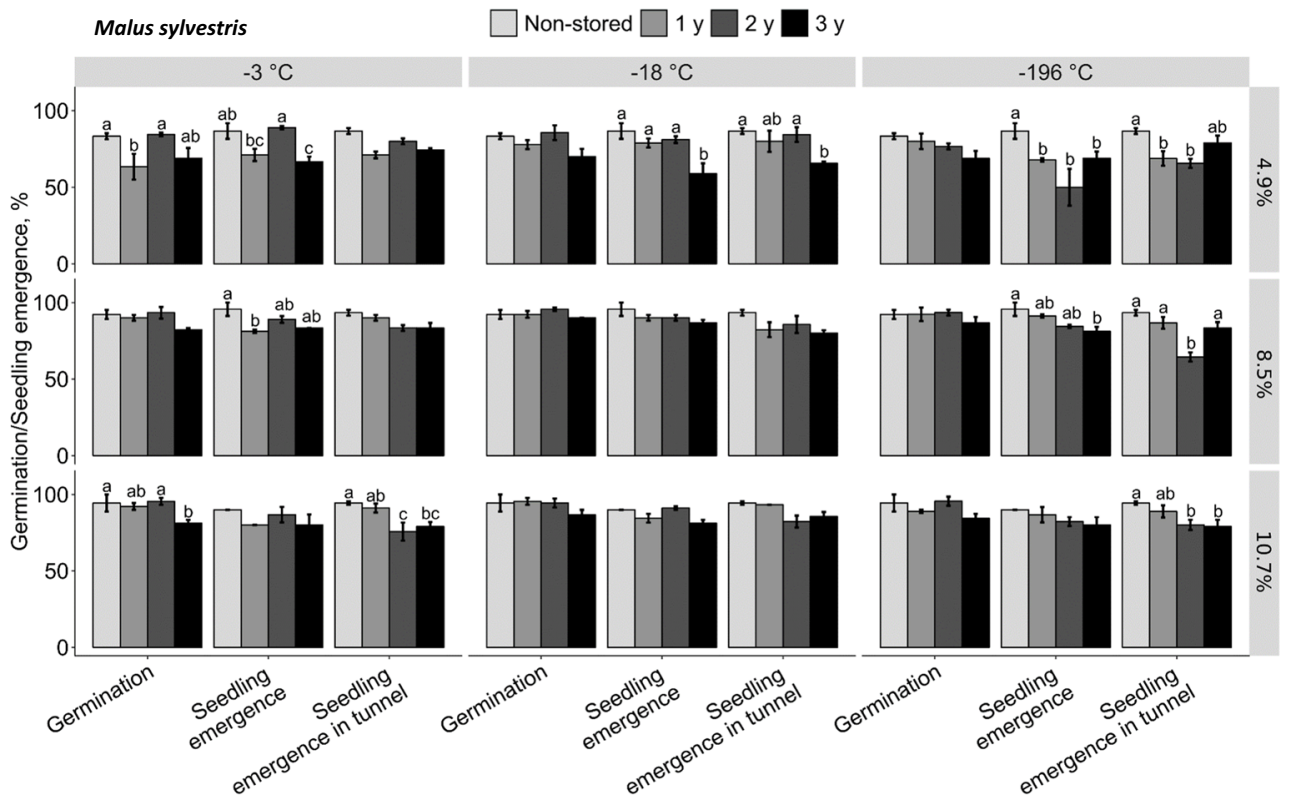

INRAC פ Springer 
Fig. 6 Germination and seedling emergence in laboratory and greenhouse of seeds of Prunus padus after 1,2, and 3 years of storage in controlled conditions. One-way ANOVA; columns marked with the same letter are not significantly different at $p<$ 0.05 , by Tukey's test. Means without letter marks are not significantly different at $p<0.05$. Means \pm SE

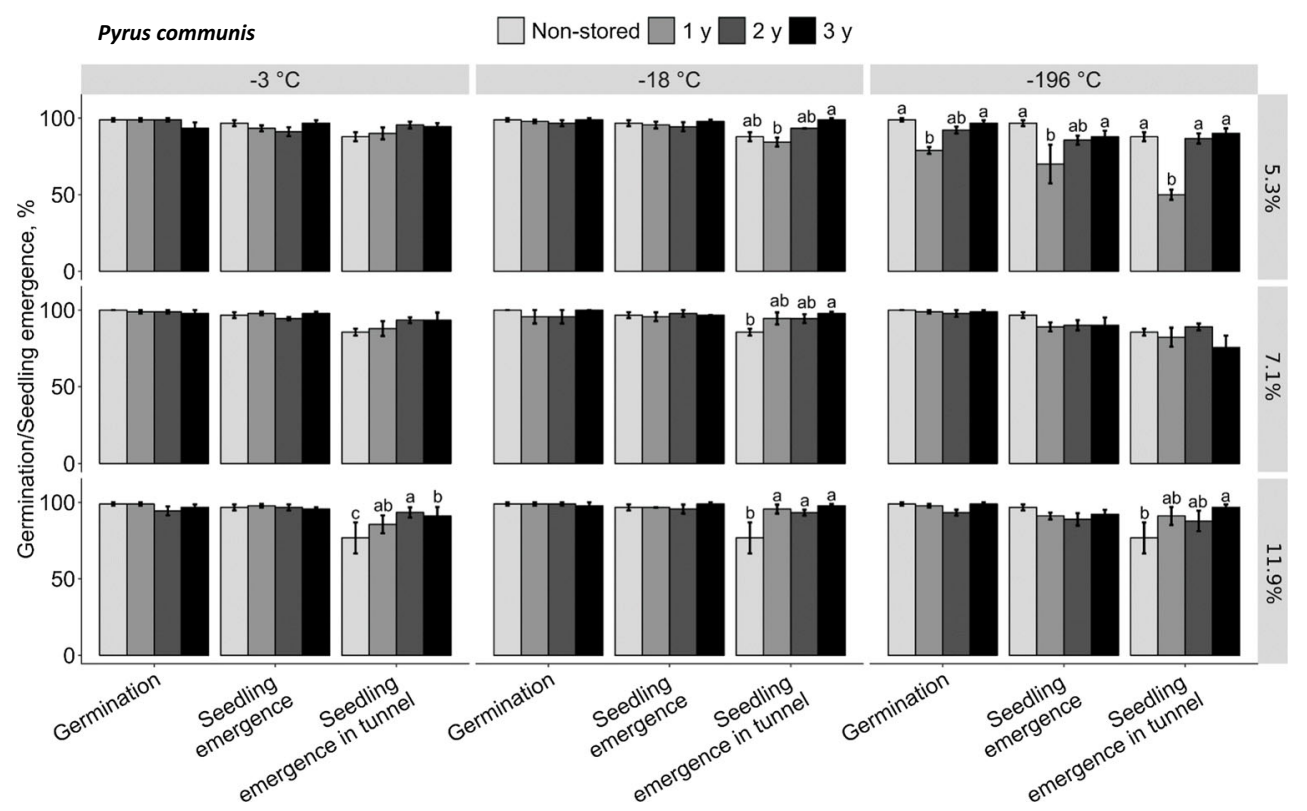

stratification never exceeded $4.5 \%$. Therefore, to hinder germination, nonstored seeds were placed at $-1{ }^{\circ} \mathrm{C}$ for 2 weeks prior to sowing. According to Afroze and O'Reilly (2015), as well as our observations (Fig. 8), freezing can result in higher germination. For confirmation, additional seeds of mountain-ash were examined, with a 2-week treatment at $-1{ }^{\circ} \mathrm{C}$ after the end of stratification. Seeds subjected to freezing germinated approximately 10 times better than the control. The lower temperature may be beneficial in breaking seed-coat-induced dormancy (Raspé et al. 2000). Perez-Garcia et al. (2009) found that, in some species of the family Brassicaceae, long-term storage increased germination due to dormancy loss. However, after the third year of storage, both the rate and total germination showed no difference from nonstored seeds. Information on the storage behavior of Cornus sanguinea seeds is scarce in the literature. The Seed Information Database (Kew Royal Botanical Gardens 2019) states that its storage behavior is uncertain. Seed survival in the transient seed bank was less than a year, which may indicate that seeds are short-lived under ambient conditions (Thompson et al. 1997). In our study, seed desiccation to $5.5 \%$ of MC did not affect germination, which reached $95 \%$ (vs. $94 \%$ in the control). The seeds remained viable at all the tested storage temperatures for 3 years; therefore, seeds of this species should be classified as orthodox. Our study shows for the first time the feasibility of cryopreservation of common dogwood seeds in the safe range of 5.5-11.0\% of MC. The seedling emergence test in the greenhouse showed much lower results than in its laboratory counterpart. This is most likely due to the late sowing date (second half of April), in which high soil temperatures could induce secondary dormancy (Benech-Arnold et al. 2000).

Seeds of Prunus padus germinate even after desiccation to $3.5 \%$ according to Popova et al. (2016). At the tested temperatures, the seeds remained viable; therefore, seeds of bird cherry can be successfully stored in conventional conditions defined by gene bank standards (FAO 2014). In the literature, for medium-term storage of this species, temperatures of $3-5^{\circ} \mathrm{C}$ with $\mathrm{MC}$ below $12 \%$ were recommended (Gordon and Rowe 1982), whereas for long-term storage, a temperature of $-18^{\circ} \mathrm{C}$ at ca. $5 \%$ of $\mathrm{MC}$ is recommended (Kew Royal Botanical Gardens 2019). Our results indicate that long-term storage of cryopreserved seeds of bird cherry is possible at all the tested MC levels (seedling emergence 76-79\%). Popova et al. (2016) report that the safe $\mathrm{MC}$ for cryogenic storage of bird cherry seeds is $3.5-15.0 \%$, which is a wider range than in other "oily" orthodox seeds. On the other hand, seeds of wild cherry in our study tolerated desiccation to MC 5.5\% and germinated at $86 \%$, compared with $90 \%$ in the control (MC 11\%). In general, wild cherry seeds are desiccation-tolerant to $1.6 \%$ of $\mathrm{MC}$ (Chmielarz, 2009; Royal Botanic Gardens Kew, 2019; Jensen and Eriksen 2001). However, partial drying of freshly collected seeds can result in a significant decrease in germination after immediate stratification and sowing (Michalak et al. 2015c). Further storage of dry seeds in tightly closed vials restores germination capacity to higher values (Suszka 1964). In our research, storage of seeds at ultralow temperatures resulted in a significant decrease in seed viability, which was detected in the seedling emergence test (although in the germination test the results were comparable), so wild cherry seed can be classified as desiccation-tolerant and LN-sensitive. Cryopreservation considerably hampers seed emergence $(66 \%$ in the laboratory and $70 \%$ in a greenhouse) but is feasible at a narrow range of seed MC (Chmielarz, 2009). The cited study suggests that low tolerance to subzero temperatures may result from the high content (45\%) and composition of storage lipids in the seeds of wild cherry. Damages can occur during changes in the phase transitions of the membranes from liquid to 
crystalline (Stanwood 1985). A similar composition of seed storage lipids is also observed in Hippophae rhamnoides, which-like wild cherry—germinates but does not develop into viable seedlings after storage in LN (Wawrzyniak unpublished). Hor et al. (2005) report that there is a negative correlation between lipid content of seeds and unfrozen water, which affects their ability to regenerate after exposure to LN. Out of the investigated 6 species, Prunus avium, Pyrus communis, and M. sylvestris seeds do not fully tolerate storage in $\mathrm{LN}$ after severe desiccation to $\mathrm{MC}$ ca. 5\%. However, in contrast to Prunus avium and Pyrus communis, whose seeds tolerate desiccation to MC 5\%, M. sylvestris seeds are negatively affected by severe desiccation to MC ca. 5\%. S. aucuparia, Prunus padus, and $C$. sanguinea seeds tolerate storage in $\mathrm{LN}$ at $\mathrm{MC}$ ca. $5 \%$.

Although there are many publications describing the effect of seed storage on germination, few studies have addressed the further growth of seedlings. For example, seedlings of Coffea arabica grown from seeds stored for 9 months at $10-11 \%$ of $\mathrm{MC}$ and $10-15{ }^{\circ} \mathrm{C}$ were not suitable for nursery planting. Additionally, seedlings grown from seeds stored at $18 \%$ of MC and $20^{\circ} \mathrm{C}$ were $50 \%$ shorter than from those stored at higher MC levels (da Rosa et al. 2011). Mucha et al. (2015) showed that seed storage temperature influences the root anatomy of black poplar (Populus nigra) and consequently may alter nutrient absorption. Good-quality seedlings with greater height and root collar diameter confer a higher chance of survival in natural conditions (Grossnickle 2012). Therefore, we conducted field research after the first year of the growing season in the greenhouse. In all the tested species, seedling emergence in the greenhouse was slightly lower than in laboratory conditions but still high, regardless of storage conditions. The height and the root collar diameter differ significantly between the tested years but probably due to differences in temperatures during the growing season (Table 7) rather than seed storage time. Differences in morphological attributes at different moisture levels and temperatures were small and did not affect seedling quality despite their statistical significance. However, this is not always the case. Arguedas et al. (2018) found that seedlings of corn (Zea mays) grown from cryostored seeds had delayed growth, although they did not differ phenotypically. The measurements in our study were made only at the end of the growing season, so we cannot conclude whether any differences were visible at the initial phase of growth. However, even if there were any differences initially, the seedlings from all the tested variants evened out by the end of the season.

Basing on our results, we can recommend storing seeds of Malus sylvestris at $-18^{\circ} \mathrm{C}$ and ca. $8 \%$. For seeds of Prunus avium, the safest temperature for storage is $-3{ }^{\circ} \mathrm{C}$. Desiccation to ca. $8 \%$ before storage at low temperature can be recommended for seeds of Sorbus aucuparia. In the case of Pyrus communis, severe desiccation should be avoided if storage in LN is planned. Prunus padus and Cornus sanguinea can be safely stored at low seed MC and temperature, as they proved to be the most tolerant. All the tested seed storage methods can be successfully used in nursery production, as no or minimal morphological differences occurred in seedling growth.

\section{Conclusion}

The results of the study show the importance of species-oriented approaches, as even in related species (both taxonomically and ecologically), seeds responded differently to given moisture content levels and storage temperatures $\left(5-11 \%\right.$ and $-196^{\circ},-18^{\circ},-3$ ${ }^{\circ} \mathrm{C}$ ). Ourresearch showed that, interms of storage behavior, (i) seeds of M. sylvestris lose viability afterdesiccationbelow $6 \% \mathrm{MCdespite}$ being considered desiccation-tolerant; (ii) desiccation of P. communis seeds to ca. 5\% MC decreases their storability in $\mathrm{LN}$; (iii) S. aucuparia seeds are beststored at $-3^{\circ} \mathrm{C}$, below $11 \% \mathrm{MC}$; (iv) $P$. avium seeds, due to damage after cryopreservation and at $-18^{\circ} \mathrm{C}$ storage, should be describe as desiccation-tolerant and sensitive to low temperatures (below $-18^{\circ} \mathrm{C}$ ); (v) seeds of $P$. communis, P. padus, and C. sanguinea can be stored long term at $-18^{\circ} \mathrm{C}$ or in LN at 5-8\% MC without losing viability; (vi) seeds of $P$. padus should be classified as orthodox; (vii) seeds of C. sanguinea are, for the first time, shown to be feasible for cryopreservation between 5.5 and $11 \% \mathrm{MC}$ and should be considered an orthodox type; and (viii) seedlings grown from seeds stored for up to 3 years in the presented storage conditions showsmallornomorphologicaldifferencesafter the first growing season and can be utilized for nursery production.

In general, species with deeper physiological dormancy (S. aucuparia, $P$. padus, C. sanguinea) tended to be more tolerant to desiccation and low temperatures. However, our study confirms that severe desiccation can damage some seeds even if classified before as orthodox species. Therefore, more accurate experiments on the long-term storage of seeds of woody species should be conducted, especially for species subject to rapid environmental changes.

Acknowledgments The authors would like to thank Magdalena Sobczak, Danuta Szymańska, and Elżbieta Drzewiecka-Pieniężna for providing technical assistance. We would also like to thank Prof. Tadeusz Tylkowski for helping with the experimental design. Research was supported by the Institute of Dendrology Polish Academy of Sciences in Kórnik, and Department of Plant Physiology, Genetics and Biotechnology, University of Warmia and Mazury in Olsztyn.

Funding information This research was funded by a grant from the General Directorate of State Forests in Warsaw, Poland (OR 2717-2/ 12). Additional support was provided by the Institute of Dendrology of the Polish Academy of Sciences.

Data availability The datasets generated and analyzed during the current study are available in the Figshare repository (https://doi.org/10.6084/m9. figshare.9080513.v2).

\section{Compliance with ethical standards}

Conflict of interest The authors declare that they have no conflict of interest. 


\section{Appendix}

Table 7 Monthly mean temperatures and minimum and maximum temperatures in greenhouse recorded during experiment in greenhouse and air and ground levels

\begin{tabular}{|c|c|c|c|c|c|c|c|}
\hline \multirow[t]{2}{*}{ Year } & \multirow[t]{2}{*}{ Month } & \multicolumn{2}{|c|}{ Mean temperature, ${ }^{\circ} \mathrm{C}$} & \multicolumn{2}{|c|}{ Air temperature, ${ }^{\circ} \mathrm{C}$} & \multicolumn{2}{|c|}{ Ground temperature, ${ }^{\circ} \mathrm{C}$} \\
\hline & & Air & Ground & Min & Max & Min & Max \\
\hline \multirow[t]{7}{*}{2013} & Apr & 13.1 & 12.6 & 2.8 & 27.7 & 1.8 & 28.2 \\
\hline & May & 16.7 & 15.8 & 4.5 & 34.4 & 3.0 & 35.7 \\
\hline & Jun & 19.3 & 18.4 & 8.2 & 35.7 & 7.1 & 36.9 \\
\hline & Jul & 20.3 & 19.5 & 11.0 & 33.4 & 9.8 & 36.6 \\
\hline & Aug & 18.1 & 18.0 & 9.6 & 34.6 & 10.6 & 38.6 \\
\hline & Sep & 12.0 & 12.4 & 2.2 & 19.4 & 5.2 & 20.9 \\
\hline & Oct & 5.0 & 6.0 & 0.1 & 10.9 & 2.7 & 10.1 \\
\hline \multirow[t]{7}{*}{2014} & Apr & 12.6 & 13.0 & -2.2 & 34.1 & 0.7 & 27.8 \\
\hline & May & 15.3 & 14.7 & -0.9 & 37.8 & 2.6 & 28.9 \\
\hline & Jun & 17.4 & 16.4 & 5.8 & 35.5 & 8.7 & 28.3 \\
\hline & Jul & 21.2 & 20.2 & 8.6 & 33.3 & 11.5 & 27.8 \\
\hline & Aug & 16.9 & 16.6 & 4.8 & 34.7 & 8.7 & 25.2 \\
\hline & Sep & 15.4 & 15.2 & 6.3 & 26.5 & 6.5 & 23.7 \\
\hline & Oct & 11.8 & 11.5 & 4.7 & 18.5 & 4.2 & 18.1 \\
\hline \multirow[t]{7}{*}{2015} & Apr & - & 14.3 & - & - & 5.7 & 27.4 \\
\hline & May & - & 15.9 & - & - & 4.9 & 28.2 \\
\hline & Jun & - & 17.2 & - & - & 11.8 & 28.8 \\
\hline & Jul & - & 19.2 & - & - & 12.7 & 26.9 \\
\hline & Aug & - & 19.3 & - & - & 12.1 & 26.5 \\
\hline & Sep & - & 14.0 & - & - & 7.8 & 23.6 \\
\hline & Oct & - & 9.6 & - & - & 5.6 & 14.9 \\
\hline \multirow[t]{7}{*}{2016} & Apr & 12.5 & 11.9 & -2.3 & 38.4 & 1.9 & 23.9 \\
\hline & May & 18.8 & 17.2 & 2.5 & 44.5 & 6.7 & 30.4 \\
\hline & Jun & 21.8 & 18.4 & 6.1 & 46.9 & 10.5 & 27.1 \\
\hline & Jul & 21.9 & 18.6 & 9.4 & 44.0 & 12.9 & 24.9 \\
\hline & Aug & 19.5 & 17.3 & 7.4 & 40.8 & 11.9 & 23.5 \\
\hline & Sep & 16.7 & 14.9 & 2.5 & 36.5 & 7.4 & 21.6 \\
\hline & Oct & 12.2 & 12.0 & 4.6 & 22.9 & 4.5 & 21.0 \\
\hline
\end{tabular}


Table 8 Full model results for examined species. Analysis of deviance results for germination percentage and seedling emergence in controlled conditions and greenhouse at $p<0.005$. Significant differences are marked in italics

\begin{tabular}{|c|c|c|c|c|c|c|c|c|c|c|c|c|c|}
\hline Factor & $d f$ & Deviance & $\begin{array}{l}\text { Resid. } \\
\text { Df }\end{array}$ & $\begin{array}{l}\text { Resid. } \\
\text { Dev }\end{array}$ & $\operatorname{Pr}(>$ chi $)$ & Deviance & $\begin{array}{l}\text { Resid. } \\
\text { Df }\end{array}$ & $\begin{array}{l}\text { Resid. } \\
\text { Dev }\end{array}$ & $\operatorname{Pr}(>$ chi $)$ & Deviance & $\begin{array}{l}\text { Resid. } \\
\text { Df }\end{array}$ & $\begin{array}{l}\text { Resid. } \\
\text { Dev }\end{array}$ & $\operatorname{Pr}(>\mathrm{ch}$ \\
\hline & \multicolumn{4}{|c|}{ Germination percentage } & & \multicolumn{3}{|c|}{ Seedling emergence } & & \multicolumn{2}{|c|}{ SE in greenhouse } & & \\
\hline M. sylvestris NULL & & & 107 & 291.93 & & & 107 & 295.501 & & & 107 & 291.93 & \\
\hline Storage (ST) & 3 & 51.468 & 104 & 240.461 & $<0.000$ & 64.979 & 104 & 230.522 & $<0.000$ & 51.468 & 104 & 240.461 & $<0.000$ \\
\hline $\begin{array}{l}\text { Moisture content } \\
\text { (MC) }\end{array}$ & 1 & 127.375 & 102 & 113.087 & $<0.000$ & 83.047 & 102 & 147.476 & $<0.000$ & 127.375 & 102 & 113.087 & $<0.000$ \\
\hline Temperature (T) & 1 & 4.404 & 100 & 108.682 & 0.130 & 7.760 & 100 & 139.716 & 0.021 & 4.404 & 100 & 108.682 & 0.130 \\
\hline $\mathrm{ST} \times \mathrm{MC}$ & 6 & 8.962 & 94 & 99.72 & 0.218 & 4.269 & 94 & 135.447 & 0.640 & 8.962 & 94 & 99.72 & 0.218 \\
\hline $\mathrm{ST} \times \mathrm{T}$ & 6 & 4.959 & 88 & 94.761 & 0.598 & 28.576 & 88 & 106.871 & $<0.000$ & 4.959 & 88 & 94.761 & 0.598 \\
\hline $\mathrm{MC} \times \mathrm{T}$ & 4 & 0.72 & 84 & 94.041 & 0.955 & 6.849 & 84 & 100.022 & 0.144 & 0.72 & 84 & 94.041 & 0.955 \\
\hline $\mathrm{ST} \times \mathrm{MC} \times \mathrm{T}$ & 12 & 7.183 & 72 & 86.858 & 0.880 & 14.950 & 72 & 85.072 & 0.244 & 7.183 & 72 & 86.858 & 0.880 \\
\hline P. communis NULL & & & 107 & 195.028 & & & 107 & 221.36 & & & 107 & 476.04 & \\
\hline Storage (ST) & 3 & 17.317 & 104 & 177.711 & 0.001 & 21.076 & 104 & 200.29 & $<0.000$ & 35.364 & 104 & 440.67 & 0.003 \\
\hline $\begin{array}{l}\text { Moisture content } \\
\text { (MC) }\end{array}$ & 1 & 15.856 & 102 & 161.854 & $<0.000$ & 15.370 & 102 & 184.92 & 0.001 & 4.308 & 102 & 436.36 & 0.423 \\
\hline Temperature (T) & 1 & 11.251 & 100 & 150.603 & 0.006 & 51.162 & 100 & 133.75 & $<0.000$ & 36.280 & 100 & 400.09 & 0.001 \\
\hline $\mathrm{ST} \times \mathrm{MC}$ & 6 & 16.077 & 94 & 134.527 & 0.023 & 7.732 & 94 & 126.02 & 0.348 & 54.197 & 94 & 345.89 & 0.001 \\
\hline $\mathrm{ST} \times \mathrm{T}$ & 6 & 17.507 & 88 & 117.019 & 0.014 & 14.043 & 88 & 111.98 & 0.058 & 52.533 & 88 & 293.36 & 0.002 \\
\hline $\mathrm{MC} \times \mathrm{T}$ & 4 & 12.630 & 84 & 104.389 & 0.021 & 1.430 & 84 & 110.55 & 0.871 & 33.482 & 84 & 259.87 & 0.010 \\
\hline $\mathrm{ST} \times \mathrm{MC} \times \mathrm{T}$ & 12 & 11.437 & 72 & 92.953 & 0.576 & 6.225 & 72 & 104.33 & 0.943 & 43.818 & 72 & 216.06 & 0.131 \\
\hline S. aucuparia NULL & & & 107 & 291.930 & & & 143 & 252.628 & & & 143 & 625.13 & \\
\hline Storage (ST) & 3 & 51.468 & 104 & 240.461 & $<0.000$ & 56.859 & 140 & 195.768 & $<0.000$ & 305.665 & 140 & 319.46 & $<0.000$ \\
\hline $\begin{array}{l}\text { Moisture content } \\
\text { (MC) }\end{array}$ & 1 & 127.375 & 102 & 113.087 & $<0.000$ & 25.410 & 138 & 170.358 & $<0.000$ & 0.781 & 138 & 318.68 & 0.821 \\
\hline Temperature (T) & 1 & 4.404 & 100 & 108.682 & 0.1303 & 7.688 & 136 & 162.670 & 0.021 & 10.587 & 136 & 308.10 & 0.070 \\
\hline $\mathrm{ST} \times \mathrm{MC}$ & 6 & 8.962 & 94 & 99.720 & 0.2175 & 31.505 & 130 & 131.165 & $<0.000$ & 39.353 & 130 & 268.74 & 0.003 \\
\hline $\mathrm{ST} \times \mathrm{T}$ & 6 & 4.959 & 88 & 94.761 & 0.5975 & 8.199 & 124 & 122.966 & 0.22390 & 7.854 & 124 & 260.89 & 0.683 \\
\hline $\mathrm{MC} \times \mathrm{T}$ & 4 & 0.720 & 84 & 94.041 & 0.9554 & 3.488 & 120 & 119.478 & 0.47976 & 17.896 & 120 & 242.99 & 0.061 \\
\hline $\mathrm{ST} \times \mathrm{MC} \times \mathrm{T}$ & 12 & 7.183 & 72 & 86.858 & 0.8801 & 25.103 & 108 & 94.375 & 0.014 & 23.473 & 108 & 219.52 & 0.460 \\
\hline$P$. avium & & & 107 & 194.012 & & & 107 & 475.76 & & & 107 & 395.79 & \\
\hline Storage (ST) & 3 & 9.372 & 104 & 184.640 & 0.025 & 78.191 & 104 & 397.57 & $<0.000$ & 54.332 & 104 & 341.46 & $<0.000$ \\
\hline $\begin{array}{l}\text { Moisture content } \\
\text { (MC) }\end{array}$ & 1 & 9.601 & 102 & 175.038 & 0.008 & 11.509 & 102 & 386.06 & 0.006 & 0.083 & 102 & 341.38 & 0.960 \\
\hline Temperature (T) & 1 & 57.200 & 100 & 117.838 & $<0.000$ & 216.815 & 100 & 169.25 & $<0.000$ & 178.036 & 100 & 163.34 & $<0.000$ \\
\hline $\mathrm{ST} \times \mathrm{MC}$ & 6 & 2.290 & 94 & 115.548 & 0.891 & 20.861 & 94 & 148.39 & 0.005 & 4.766 & 94 & 158.57 & 0.592 \\
\hline $\mathrm{ST} \times \mathrm{T}$ & 6 & 33.691 & 88 & 81.857 & $<0.000$ & 46.782 & 88 & 101.60 & $<0.000$ & 58.665 & 88 & 99.91 & $<0.000$ \\
\hline $\mathrm{MC} \times \mathrm{T}$ & 4 & 2.474 & 84 & 79.383 & 0.649 & 7.074 & 84 & 94.53 & 0.178968 & 5.831 & 84 & 94.08 & 0.225 \\
\hline $\mathrm{ST} \times \mathrm{MC} \times \mathrm{T}$ & 12 & 7.139 & 72 & 72.244 & 0.848 & 8.393 & 72 & 86.14 & 0.826162 & 17.744 & 72 & 76.33 & 0.140 \\
\hline P. padus & & & 107 & 149.908 & & & 107 & 174.590 & & & 107 & 186.38 & \\
\hline Storage (ST) & 3 & 2.9922 & 104 & 146.916 & 0.464 & 49.258 & 104 & 125.332 & $<0.000$ & 14.6270 & 104 & 171.75 & 0.039 \\
\hline $\begin{array}{l}\text { Moisture content } \\
\text { (MC) }\end{array}$ & 1 & 0.4769 & 102 & 146.439 & 0.815 & 4.471 & 102 & 120.862 & 0.155 & 1.0992 & 102 & 170.65 & 0.730 \\
\hline Temperature (T) & 1 & 3.5758 & 100 & 142.863 & 0.216 & 0.493 & 100 & 120.369 & 0.814 & 0.2878 & 100 & 170.36 & 0.921 \\
\hline $\mathrm{ST} \times \mathrm{MC}$ & 6 & 25.3883 & 94 & 117.475 & 0.001 & 7.444 & 94 & 112.925 & 0.400 & 16.8253 & 94 & 153.54 & 0.140 \\
\hline $\mathrm{ST} \times \mathrm{T}$ & 6 & 9.0377 & 88 & 108.437 & 0.257 & 5.175 & 88 & 107.750 & 0.634 & 0.5558 & 88 & 152.98 & 0.999 \\
\hline $\mathrm{MC} \times \mathrm{T}$ & 4 & 1.1001 & 84 & 107.337 & 0.918 & 9.074 & 84 & 98.675 & 0.109 & 3.4763 & 84 & 149.50 & 0.737 \\
\hline $\mathrm{ST} \times \mathrm{MC} \times \mathrm{T}$ & 12 & 13.1876 & 72 & 94.149 & 0.503 & 10.898 & 72 & 87.778 & 0.695 & 17.4509 & 72 & 132.06 & 0.615 \\
\hline C. sanguinea NULL & & & 143 & 285.87 & & & 143 & 401.12 & & & 143 & 247.42 & \\
\hline Storage (ST) & 3 & 41.739 & 140 & 244.13 & $<0.000$ & 148.022 & 140 & 253.10 & $<0.000$ & 12.366 & 140 & 235.05 & 0.060 \\
\hline & 1 & 4.444 & 138 & 239.69 & 0.272 & 0.520 & 138 & 252.58 & 0.840 & 0.584 & 138 & 234.47 & 0.831 \\
\hline
\end{tabular}


Table 8 (continued)

\begin{tabular}{|c|c|c|c|c|c|c|c|c|c|c|c|c|c|}
\hline Factor & $d f$ & Deviance & $\begin{array}{l}\text { Resid. } \\
\text { Df }\end{array}$ & $\begin{array}{l}\text { Resid. } \\
\text { Dev }\end{array}$ & $\operatorname{Pr}(>$ chi $)$ & Deviance & $\begin{array}{l}\text { Resid. } \\
\text { Df }\end{array}$ & $\begin{array}{l}\text { Resid. } \\
\text { Dev }\end{array}$ & $\operatorname{Pr}(>$ chi $)$ & Deviance & $\begin{array}{l}\text { Resid. } \\
\text { Df }\end{array}$ & $\begin{array}{l}\text { Resid. } \\
\text { Dev }\end{array}$ & $\operatorname{Pr}(>$ chi $)$ \\
\hline \multicolumn{14}{|l|}{$\begin{array}{l}\text { Moisture content } \\
\text { (MC) }\end{array}$} \\
\hline Temperature (T) & 1 & 3.176 & 136 & 236.51 & 0.395 & 3.018 & 136 & 249.56 & 0.365 & 3.227 & 136 & 231.24 & 0.361 \\
\hline $\mathrm{ST} \times \mathrm{MC}$ & 6 & 8.430 & 130 & 228.08 & 0.552 & 26.235 & 130 & 223.33 & 0.008 & 12.646 & 130 & 218.59 & 0.239 \\
\hline $\mathrm{ST} \times \mathrm{T}$ & 6 & 8.974 & 124 & 219.11 & 0.512 & 18.160 & 124 & 205.17 & 0.059 & 7.793 & 124 & 210.80 & 0.553 \\
\hline $\mathrm{MC} \times \mathrm{T}$ & 4 & 4.166 & 120 & 214.94 & 0.656 & 5.745 & 120 & 199.42 & 0.428 & 8.834 & 120 & 201.97 & 0.232 \\
\hline $\mathrm{ST} \times \mathrm{MC} \times \mathrm{T}$ & 12 & 9.950 & 108 & 204.99 & 0.925 & 11.397 & 108 & 188.03 & 0.815 & 31.910 & 108 & 170.06 & 0.064 \\
\hline
\end{tabular}

Fig. 3 Germination and seedling emergence in laboratory and greenhouse of seeds of Pyrus communis after 1, 2, and 3 years of storage in controlled conditions. One-way ANOVA; columns marked with the same letter are not significantly different at $p<0.05$, by Tukey's test. Means without letter marks are not significantly different at $p<$ 0.05 . Means $\pm \mathrm{SE}$
Fig. 4 Germination and seedling emergence in laboratory and greenhouse of seeds of Sorbus aucuparia after 1, 2, and 3 years of storage in controlled conditions. One-way ANOVA; columns marked with the same letter are not significantly different at $p<0.05$, by Tukey's test Means without letter marks are not significantly different at $p<$ 0.05 . Means $\pm \mathrm{SE}$
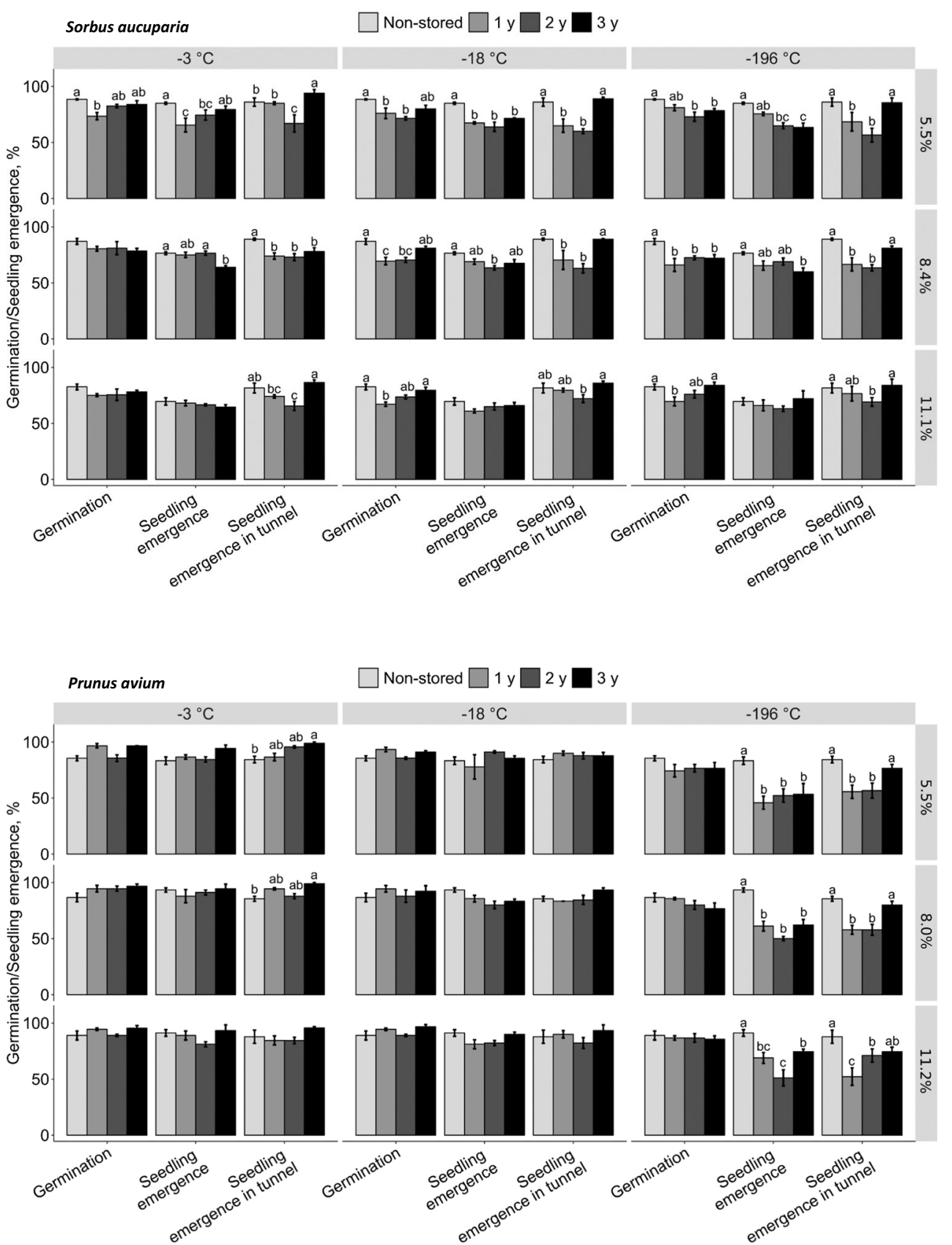
Fig. 5 Germination and seedling emergence in laboratory and greenhouse of seeds of Prunus avium after 1,2, and 3 years of storage in controlled conditions. One-way ANOVA; columns marked with the same letter are not significantly different at $p<$ 0.05 , by Tukey's test. Means without letter marks are not significantly different at $p<0.05$.

Means \pm SE
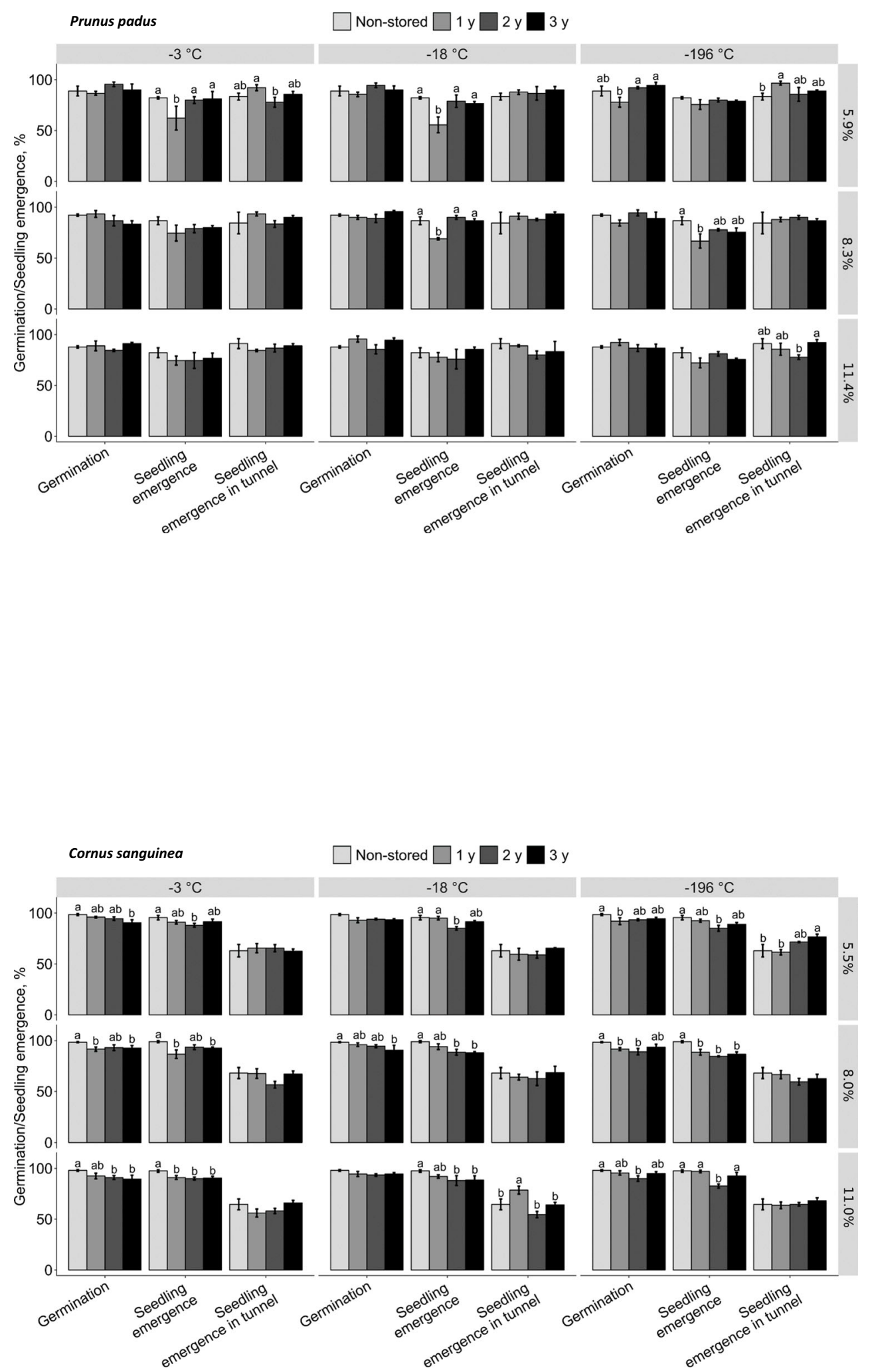

Fig. 7 Germination and seedling emergence in laboratory and greenhouse of seeds of Cornus sanguinea after 1, 2, and 3 years of storage in controlled conditions. $p<0.005$, Tukey test. One-way ANOVA; columns marked with the same letter are not significantly different at $p<$ 0.05 , by Tukey's test. Means without letter marks are not significantly different at $p<0.05$. Means \pm SE

INRAC פspringer 
Fig. 8 Germination rate of seeds of Sorbus aucuparia after stratification in $3{ }^{\circ} \mathrm{C}$ and no additional storage (control) or with additional freezing in 2week storage in $-3{ }^{\circ} \mathrm{C}$ (freeze). Error bars represent standard error for mean. Additional test was made for 3 replicates per 30 seeds, after 1 year storage in $-3{ }^{\circ} \mathrm{C}$

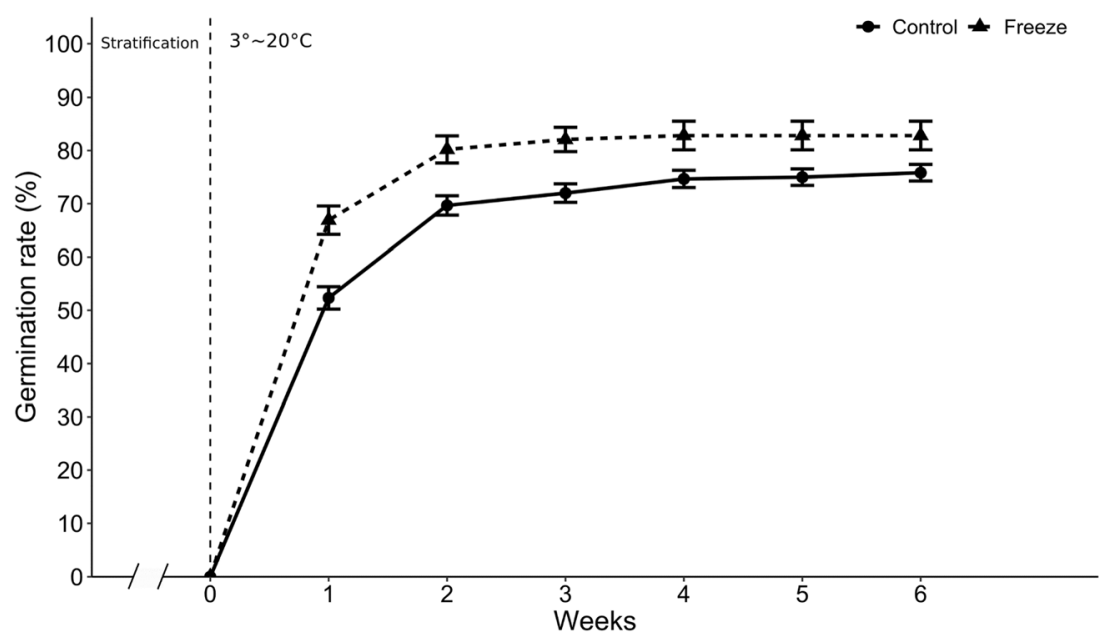

Open Access This article is licensed under a Creative Commons Attribution 4.0 International License, which permits use, sharing, adaptation, distribution and reproduction in any medium or format, as long as you give appropriate credit to the original author(s) and the source, provide a link to the Creative Commons licence, and indicate if changes were made. The images or other third party material in this article are included in the article's Creative Commons licence, unless indicated otherwise in a credit line to the material. If material is not included in the article's Creative Commons licence and your intended use is not permitted by statutory regulation or exceeds the permitted use, you will need to obtain permission directly from the copyright holder. To view a copy of this licence, visit http://creativecommons.org/licenses/by/4.0/.

\section{References}

Afroze F, O'Reilly C (2015) Effect of harvest date, drying, short-term storage and freezing after chilling on the germination of rowan seeds. Scand J Forest Res 31:339-346. https://doi.org/10.1080/ 02827581.2015 .1080293

Angelovici R, Galili G, Fernie AR et al (2010) Seed desiccation. A bridge between maturation and germination. Trends Plant Sci 15:211-218. https://doi.org/10.1016/j.tplants.2010.01.003

Arguedas M, Gómez D, Hernández L et al (2018) Maize seed cryostorage modifies chlorophyll, carotenoid, protein, aldehyde and phenolics levels during early stages of germination. Acta Physiol Plant 40:177. https://doi.org/10.1007/s11738-018-2695-7

Benech-Arnold RL, Sánchez RA, Forcella F et al (2000) Environmental control of dormancy in weed seed banks in soil. Field Crop Res 67: 105-122. https://doi.org/10.1016/S0378-4290(00)00087-3

Benamirouche S, Chouial M, Messaoudene M (2018) Storage of cork oak (Quercus suber L., 1753) acorns and effect of storage duration on seedlings vigour: artificial regeneration implications. Revue d'Écologie 73:80-95

Bleeker W, Schmitz U, Ristow M (2007) Interspecific hybridisation between alien and native plant species in Germany and its consequences for native biodiversity. Biol Conserv 137:248-253. https://doi.org/10.1016/j.biocon.2007.02.004

Campo AD, Navarro RM, Ceacero CJ (2010) Seedling quality and field performance of commercial stocklots of containerized holm oak (Quercus ilex) in Mediterranean Spain: an approach for establishing a quality standard. New Forest 39:19-37. https://doi.org/10.1007/ s11056-009-9152-9

Cardinale BJ, Duffy JE, Gonzalez A et al (2012) Biodiversity loss and its impact on humanity. Nature 486:59. https://doi.org/10.1038/ nature 11148

Carvalho FJ, Santana DGD, Araújo LBD (2018) Why analyze germination experiments using generalized linear models?. J Seed Scie., 40(3), 281-287.Chmielarz P (2009a) Cryopreservation of dormant European ash (Fraxinus excelsior) orthodox seeds. Tree Physiol 29: 1279-1285. https://doi.org/10.1093/treephys/tpp064

Chmielarz P (2009) Cryopreservation of dormant orthodox seeds of forest trees. Mazzard cherry (Prunus avium L.). Ann For Sci 66:1-9. https://doi.org/10.1051/forest/2009020

Chmielarz P (2010) Cryopreservation of orthodox seeds of Alnus glutinosa. CryoLetters 31:139-146

Coart E, Vekemans X, Smulders MJM et al (2003) Genetic variation in the endangered wild apple (Malus sylvestris (L.) Mill.) in Belgium as revealed by amplified fragment length polymorphism and microsatellite markers. Mol Ecol 12:845-857. https://doi.org/10.1046/j. 1365-294X.2003.01778.x

da Rosa SDVF, Carvalho AM, McDonald MB et al (2011) The effect of storage conditions on coffee seed and seedling quality. Seed Sci Technol 39:151-164. https://doi.org/10.15258/sst.2011.39.1.13

Debeaujon I, Léon-Kloosterziel KM, Koornneef M (2000) Influence of the testa on seed dormancy, germination, and longevity in Arabidopsis. Plant Physiol 122:403-414

Dirlewanger E, Cosson P, Tavaud M et al (2002) Development of microsatellite markers in peach [Prunus persica (L.) Batsch] and their use in genetic diversity analysis in peach and sweet cherry (Prunus avium L.). Theor Appl Genet 105:127-138. https://doi.org/10. 1007/s00122-002-0867-7

EEA (2016) European forest ecosystems. State and trends. European Environment Agency https://www.eea.europa.eu/publications/ Accessed 10 May 2019

Ellis R (1995) Survival and vigour of lettuce (Lactuca sativa L.) and sunflower (Helianthus annuus L.) seeds stored at low and verylow moisture contents. Ann Bot 76:521-534. https://doi.org/10. 1006/anbo.1995.1128

Ellis RH, Hong TD, Astley D et al. (1996) Survival of dry and ultra-dry seeds of carrot, groundnut, lettuce, oilseed rape, and onion during five years' hermetic storage at low temperatures. Seed Sci. Technol. (Switzerland) 24(2) 
Ellis RH, Hong TD, Roberts EH (1986) Logarithmic relationship between moisture content and longevity in sesame seeds. Ann Bot 57:499-503. https://doi.org/10.1093/oxfordjournals.aob.a08713

FAO (2014) The state of the world's forest genetic resources. Food and Agriculture Organization of the United Nations, Rome

FAO (2015) Coping with climate change. The roles of genetic resources for food and agriculture. Food and Agriculture Organization of the United Nations, Rome

Fellenberg U, Kadolsky M, Rumpf $\mathrm{H}$ et al (2000) Wild fruit trees and shrubs as an integrated part of conservation and utilization of forest genetic resources in north west Germany. Acta Hortic 538:63-66

Forest Europe (2015) State of Europe's forests 2015. Europe's status \& trends in sustainable forest management in Europe. Project coordinator: Martin M, Forest Europe. Liaison Unit Madrid

Gordon AG, Faulkner R, Lines R et al. (1992) Seed manual for forest trees. Forest Commission UK

Gordon AG, Rowe DCF (1982). Seed manual for trees and shrubs. For. Comm. Bull. 59. London United Kingdom Forestry Commission

Granstrom A (1987) Seed viability of fourteen species during five years of storage in a forest soil. J Ecol 75:321. https://doi.org/10.2307/ 2260421

Grossnickle SC (2005) Seedling size and reforestation success. How big is big enough? In: Colombo SJ (Compiler) The thin green line: a symposium on the state-of-the-art in reforestation. Ont. For. Res. Inst., Ontario Ministry of Natural Resources. For Res Info Paper 160:138-144

Grossnickle SC (2012) Why seedlings survive. Influence of plant attributes. New For 43:711-738. https://doi.org/10.1007/s11056-0129336-6

Haiying Z, Shuchun M, Xianghui K (2002) Effect of ultra-dry storage on viability and vigor of tomato seeds. Acta Hort Sinica 29:35-38

Hong TD, Ellis RH, Astley D et al (2005) Survival and vigour of ultra-dry seeds after ten years of hermetic storage. Seed Sci Technol 33:449 460. https://doi.org/10.15258/sst.2005.33.2.17

Hooper DU, Chapin FS, Ewel JJ et al (2005) Effects of biodiversity on ecosystem functioning. A consensus of current knowledge. Ecol Monogr 75:3-35. https://doi.org/10.1890/04-0922

Hor YL, Kim YJ, Ugap A et al (2005) Optimal hydration status for cryopreservation of intermediate oily seeds. Citrus as a case study. Ann Bot 95:1153-1161. https://doi.org/10.1093/aob/mci126

Isbell F, Craven D, Connolly J et al (2015) Biodiversity increases the resistance of ecosystem productivity to climate extremes. Nature 526:574-577. https://doi.org/10.1038/nature15374

Jaganathan GK, Wu GR, Song XY et al (2015) Cryopreservation of dormant Prunus armeniaca L. seeds. Seed Sci Technol 43:456466. https://doi.org/10.15258/sst.2015.43.3.11

Jactel H, Bauhus J, Boberg J et al (2017) Tree diversity drives forest stand resistance to natural disturbances. Curr For Rep 3:223-243. https:// doi.org/10.1007/s40725-017-0064-1

Jensen M, Eriksen EN (2001) Development of primary dormancy in seeds of Prunus avium during maturation. Seed Sci Technol 29: 307-320

Kushnarenko S, Salnikov E, Nurtazin M et al (2010) Characterization and cryopreservation of Malus sieversii seeds. Asian Australas. J Plant Sci Biotechnol 4. https://doi.org/10.13140/RG.2.1.4609.0008

Labouriau LG (1983) A germinação das sementes. Monografias Científicas, Washington, USA

Larsen AS, Asmussen CB, Coart E et al (2006) Hybridization and genetic variation in Danish populations of European crab apple (Malus sylvestris). Tree Genet Genomes 2:86-97. https://doi.org/10.1007/ s11295-005-0030-0

Liang J, Crowther TW, Picard N et al (2016) Positive biodiversityproductivity relationship predominant in global forests. Science 354:8957. https://doi.org/10.1126/science.aaf8957
Lin TP, Huang NH (1994) The relationship between carbohydrate composition of some tree seeds and their longevity. J Exr Bot 45:12891294

Marshall AH, Lewis DN (2004) Influence of seed storage conditions on seedling emergence, seedling growth and dry matter production of temperate forage grasses. Seed Sci Technol 32:493-501. https://doi. org/10.15258/sst.2004.32.2.19

Michalak M, Plitta BP, Chmielarz P (2013) Desiccation sensitivity and successful cryopreservation of oil seeds of European hazelnut (Corylus avellana). Ann Appl Biol 101. https://doi.org/10.1111/ aab.12059

Michalak M, Plitta BP, Tylkowski T et al (2015a) Desiccation tolerance and cryopreservation of seeds of black poplar (Populus nigra L.), a disappearing tree species in Europe. Eur J Forest Res 134:53-60. https://doi.org/10.1007/s10342-014-0832-4

Michalak M, Plitta-Michalak BP, Chmielarz P (2015b) Desiccation tolerance and cryopreservation of wild apple (Malus sylvestris) seeds. Seed Sci Technol 43:480-491. https://doi.org/10.15258/sst.2015. 43.3.20

Michalak M, Plitta-Michalak BP, Chmielarz P (2015c) A new insight in desiccation tolerance and cryopreservation of mazzard cherry (Prunus avium L.) seeds. Open. Life Sci 10:91. https://doi.org/10. 1515/biol-2015-0036

Mucha J, Szymańska AK, Zadworny M et al (2015) Effect of seed storage temperature on fine root development and mycorrhizal colonization of young Populus nigra seedlings. Ann For Sci 72:539-547. https:// doi.org/10.1007/s13595-015-0470-0

Nguyen TP, Keizer P, van Eeuwijk F, Smeekens S, Bentsink L (2012) Natural variation for seed longevity and seed dormancy are negatively correlated in Arabidopsis. Plant Physiol 160:2083-2092

Pairon M, Petitpierre B, Campbell M et al (2010) Multiple introductions boosted genetic diversity in the invasive range of black cherry (Prunus serotina; Rosaceae). Ann Bot 105:881-890. https://doi. org/10.1093/aob/mcq065

Perez-Garcia F, Gomez-Campo C, Ellis RH (2009) Successful long-term ultra dry storage of seed of 15 species of Brassicaceae in a GeneBank. Variation in ability to germinate over 40 years and dormancy. Seed Sci Technol 37:640-649. https://doi.org/10.15258/sst. 2009.37.3.12

Plitta BP, Michalak M, Kotlarski S et al (2013) Cryopreservation of forest seeds. Sylwan 157:723-729

Popova E, Moltchanova E, Han SH et al (2016) Cryopreservation of Prunus padus seeds. Emphasising the significance of Bayesian methods for data analysis. Can J For Res 46:766-774. https://doi. org/10.1139/cjfr-2016-0020

Powell B, Ickowitz A, McMullin S et al. (2013) The role of forests, trees and wild biodiversity for nutrition-sensitive food systems and landscapes. In: Expert background paper for the International Conference on Nutrition, Food and Agriculture Organization of the United Nations, Rome, Italy

Pritchard HW, Moat JF, Ferraz JB et al (2014) Innovative approaches to the preservation of forest trees. For Ecol Manag 333:88-98. https:// doi.org/10.1016/j.foreco.2014.08.012

Probert RJ, Daws MI, Hay FR (2009) Ecological correlates of ex situ seed longevity: a comparative study on 195 species. Ann Bot 104:57-69

Ranal MA, Santana DG (2006) How and why measure germination process? Rev Bras Bot 29:1-11. https://doi.org/10.1590/S010084042006000100002

Raspé O, Findlay C, Jacquemart AL (2000) Sorbus aucuparia L. J Ecol 88:910-930. https://doi.org/10.1046/j.1365-2745.2000.00502.x

Reim S, Proft A, Heinz S, Höfer M (2012) Diversity of the European indigenous wild apple Malus sylvestris (L.) MILL. in the East Ore Mountains (Osterzgebirge), Germany: I. Morphological characterization. Genet Resour Crop Ev 59:1101-1114. https://doi.org/10. 1007/s10722-011-9746-x 
R Core Team (2020) R: A language and environment for statistical computing. R Foundation for Statistical Computing, Vienna, Austria. URL https://www.R-project.org/

Royal Botanic Gardens Kew (2019) Seed Information Database (SID). Version 7.1. Available from: http://data.kew.org/sid/ Accessed 01 July 2019

Russell K (2003) EUFORGEN Technical Guidelines for genetic conservation and use for Wild cherry (Prunus avium). Bioversity International, Rome, Italy

Schulze ED, Bouriaud L, Bussler H et al (2014) Forest management and biodiversity. Web Ecol 14:3-10. https://doi.org/10.5194/we-14-32014

Stanwood PC (1985) Cryopreservation of seed germplasm for genetic conservation. In: Kartha KK (ed) Cryopreservation of plant cells and organs. CRC Press, Boca Raton, pp 199-226

Stephan BR, Wagner I, Kleinschmit J (2003) EUFORGEN technical guidelines for genetic conservation and use for wild apple and pear (Malus sylvestris and Pyrus pyraster). Bioversity International, Rome, Italy

Suszka B (1964) Influence of method and duration of stone storage on the germination capacity of the mazzard cherry (Prunus avium L.). Arboretum Kórnickie 9:223-235

Suszka B, Muller C, Bonnet-Masimbert M (1996) Seeds of forest broadleaves: from harvest to sowing. INRA, France
Thompson K, Bakker JP, Bekker RM (1997) The soil seed banks of North West Europe. Methodology, density and longevity. Cambridge University Press

Urrestarazu J, Denancé C, Ravon E et al (2016) Analysis of the genetic diversity and structure across a wide range of germplasm reveals prominent gene flow in apple at the European level. BMC Plant Biol 16:130. https://doi.org/10.1186/s12870-016-0818-0

Walters C (2007) About the limited benefit of water content and temperature on orthodox seed longevity. South Afr J Bot 73:495-496

Wawrzyniak M, Michalak M, Chmielarz P (2020) Effect of different conditions of storage on seed viability and seedling growth of six wild fruit woody plants. V2. Figshare repository. [Dataset]. https:// doi.org/10.6084/m9.figshare.9080513.v2

Wolf H, Arenhövel W, Behm A et al. (1999) Conservation and breeding of wild fruit tree species in forestry. In: Eucarpia symposium on Fruit Breeding and Genetics 538: 57-62

Wünsch A, Hormaza JI (2007) Characterization of variability and genetic similarity of European pear using microsatellite loci developed in apple. Sci Hortic 113:37-43. https://doi.org/10.1016/j.scienta.2007. 02.002

Publisher's note Springer Nature remains neutral with regard to jurisdictional claims in published maps and institutional affiliations. 